\title{
Bone morphogenetic protein 2 and activin A synergistically stimulate follicle-stimulating hormone $\beta$ subunit transcription
}

\author{
Katharine B Lee ${ }^{1}$, Vishal Khivansara ${ }^{2}$, Michelle M Santos ${ }^{2}$, Pankaj Lamba ${ }^{1,2}$, Tony Yuen ${ }^{3}$, \\ Stuart C Sealfon ${ }^{3}$ and Daniel J Bernard ${ }^{1,2}$ \\ ${ }^{1}$ Department of Pharmacology and Therapeutics, McGill University, 3655 Promenade Sir William Osler, Montréal, Québec, Canada H3G 1 Y6 \\ ${ }^{2}$ Center for Biomedical Research, Population Council and The Rockefeller University, 1230 York Avenue, New York, New York 10021, USA \\ ${ }^{3}$ Department of Neurology, Mount Sinai School of Medicine, One Gustave L. Levy Place, New York, New York 10029, USA \\ (Requests for offprints should be addressed to D J Bernard; Email: daniel.bernard@ @mcgill.ca)
}

\begin{abstract}
Transforming growth factor $\beta$ superfamily ligands regulate pituitary FSH production and secretion. The best-described examples are the activins and inhibins, which respectively stimulate and hinder Fshb subunit transcription in gonadotrope cells. More recently, members of the bone morphogenetic protein (BMP) sub-family were shown to regulate FSH production in a manner analogous to the activins. Here, we used the murine gonadotrope cell line, L $\beta$ T2, to investigate mechanisms through which BMP2 regulates the Fshb gene. Although expressed at low levels in L $\beta T 2$ cells, Bmp2 mRNA was readily detected in adult murine pituitary gland. Recombinant BMP2 stimulated Fshb promoter-reporter activity, although its effects were weaker than those of equimolar activin A or B. BMP4 stimulated transcription comparably with BMP2, but BMPs 6 and 7 were about tenfold less potent. Remarkably, BMP2 and activin A synergistically upregulated Fshb transcription and endogenous Fshb mRNA levels in L $\beta T 2$ cells. Although functionally cooperative, the two ligands appeared to use distinct intracellular mechanisms to mediate their responses because neither ligand altered the timing or magnitude of the other's effects. Receptor overexpression analyses suggested that BMP2 may preferentially signal through complexes of the type II receptor, BMPR2, and the type I receptor, activin receptor like kinase (ALK2; Acvr1), to stimulate Fshb transcription. BMP2 rapidly activated the Smad1/5/8 intracellular signaling cascade and Smad8 overexpression potentiated BMP2's effects. In summary, BMPs regulate Fshb transcription in L $\beta$ T2 cells and can amplify the already robust effects of the activins through a distinct signaling mechanism. Because BMP2 is expressed in the adult mouse pituitary, it may act as critical paracrine co-regulator of $\mathrm{FSH}$ synthesis by gonadotropes.
\end{abstract}

Journal of Molecular Endocrinology (2007) 38, 315-330

\section{Introduction}

The gonadotropin hormones, follicle-stimulating hormone (FSH) and luteinizing hormone (LH), are both coordinately and differentially regulated under various physiological conditions. In many cases, singular changes in FSH synthesis and secretion are attributable to actions of transforming growth factor (TGF) $\beta$ superfamily ligands, the activins and inhibins, in particular. Recent data show that activins stimulate FSH synthesis by upregulating FSH $\beta$ subunit gene $(F s h b)$ transcription, at least in part, through the activation of the receptor-regulated signaling proteins, Smads 2 and 3 (Dupont et al. 2003, Suszko et al. 2003, Bernard 2004, Gregory et al. 2005, Suszko et al. 2005, Lamba et al. 2006). In the case of the rat and mouse genes, these Smads, in concert with Smad4, bind to a consensus Smad-binding element in the proximal promoter to exert their actions. The promoters in sheep, pig, and human lack this element and therefore mechanisms of activin/Smad action appear to differ in these species (Bailey et al. 2004, West et al. 2004, Safwat et al. 2005, Lamba et al. 2006).

Inhibins suppress FSH through a competitive binding mechanism (Harrison et al. 2005). That is, inhibins A and B can bind to activin type II receptors (ACVR2A and ACVR2B) via the $\beta$ subunits they share with activins. In so doing, they hinder receptor access by activins, leading to decreased $F s h b$ mRNA expression. Inhibins bind with significantly lower affinity than the activins, in part because the latter contain two $\beta$ subunits and can engage two type II receptors simultaneously, whereas the former have only one $\beta$ subunit and therefore only bind one type II receptor at a time (Cook et al. 2005). Inhibins' affinity for type II receptors can be increased significantly in the presence of the co-receptor betaglycan (Lewis et al. 2000, Chapman et al. 2002). Unlike the activins, inhibins do not recruit the activin type I receptor, ACVR1B (commonly referred to as activin receptor-like kinase 4 or ALK4), into the complex and therefore cannot activate the Smad2/3pathway (Lebrun \& Vale 1997).

DOI: 10.1677/jme.1.02196 Online version via http://www.endocrinology-journals.org 
Like the inhibins, follistatins also negatively regulate FSH through abrogation of activins' actions. However, rather than competing for receptor binding, follistatins bind directly and irreversibly to activins, burying a large percentage of the ligands' surfaces, including residues involved in receptor binding (Thompson et al. 2005). Follistatin-288 (Fst-288) also appears to increase internalization of activins and their degradation through a lysosome-mediated pathway (Sugino et al. 1997). Across rodent estrous cycles, circulating inhibins and intra-pituitary follistatins are regulated in a manner consistent with their roles in activin antagonism (Woodruff et al. 1996, Besecke et al. 1997). In fact, their coordinate decline at or just after the primary gonadotropin surges on the evening of proestrus is argued to provide a permissive hormonal environment for locally produced activins to stimulate $F s h b$ subunit transcription, hence generating the secondary FSH surge in rodents.

Although elegant in its simplicity, this model of activin-induced FSH expression was recently challenged by three separate, but related observations. First, additional ligands in the TGF $\beta$ superfamily, in particular bone morphogenetic proteins (BMPs) 6, 7, and 15 were shown to selectively stimulate FSH in a manner analogous to the activins (Huang et al. 2001c, Otsuka \& Shimasaki 2002). Secondly, some follistatin isoforms can bind BMPs and hinder their biological activities (Sidis et al. 2006). Thirdly, inhibins, once thought to uniquely antagonize activin signaling, were shown to inhibit BMP actions via a ternary complex of betaglycan and type II receptors (Wiater \& Vale 2003, Wiater et al. 2006). Thus, BMPs might act alone or in concert with activins to stimulate FSH synthesis, and might, like activins, be negatively regulated by inhibins and follistatins.

Whether or not BMPs are bona fide physiological regulators of FSH in vivo remains to be determined. If they are, then their intracellular mechanisms of action are likely to differ from those of the activins. Whereas activins signal through Smads 2 and 3, BMPs use the related, but structurally distinct, receptor-regulated Smads 1, 5, and 8 (Miyazono 1999, Miyazawa et al. 2002). This raises the intriguing notion that TGF $\beta$ superfamily ligands might use multiple signaling pathways to coordinately regulate FSH synthesis. Here, we describe a candidate signaling pathway through which BMPs regulate murine Fshb transcription in gonadotrope cells.

\section{Materials and methods}

\section{Ligands and constructs}

Human recombinant (rh-) activin A, activin B, BMP2, BMP4, BMP6, and BMP7 were purchased from R\&D
Systems (Minneapolis, MN, USA). Activin A was also generously provided by Dr Teresa Woodruff (Northwestern University, Evanston, IL, USA), as were expression constructs for rat Flag-ActRIIA (Acvr2a), Flag-ActRIIB2 (Acvr2b2), HA-Acvr1 (ALK2), HA-Acvr1b (ALK4), and human Flag-Smad1. Constitutively active HA-ALK2(Q207D) and HA-rat ALK4(T206D) were generated by site-directed mutagenesis. HA-human ALK3(Q233D) was provided by Dr Peter Scheiffele (Columbia University, New York, NY, USA). Human Flag-Smad2 in pCAGGS (Dr E Roberston, Oxford University, Oxford, UK), human Flag-Smad3 and rat Myc-Smad8 (DrY Chen, Indiana University, Indianapolis, IN, USA), and human Flag-Smad5 (Dr T Watanabe, Tokyo University, Tokyo, Japan) were generously provided by the indicated investigators. The truncated Smad8 construct was produced by introduction of a premature stop codon just N-terminal to the C-terminal serines by site-directed mutagenesis. The $-1990 /+$ $1 \mathrm{~m} F$ shb-luc reporter construct and $5^{\prime}$ deletions thereof were described previously (Bernard 2004, Lamba et al. 2006). The BREX4-luc BMP-responsive reporter (Hata et al. 2000) and human BMPR2 expression construct (Liu et al. 1995) were provided by Dr Joan Massague (Memorial Sloan Kettering Cancer Center, New York, NY, USA). The $-763 /+91$ ovine Fshb-luc reporter was generated by subcloning the SacI/XhoI fragment from the parental $-4741 /+759$ oFshb-luc (gift from Dr W Miller, North Carolina State University, Raleigh, NC, USA) into the same sites in pGL3-Basic. The porcine reporter, $-767 /+$ $8 \mathrm{p} F$ shb-luc, was generated in two steps. First, -1369 to +8 was PCR amplified from genomic DNA (Novagen, porcine whole blood genomic DNA) using the following primer set and ligated into the MluI/XhoI sites of pGL3Basic: Forward, GCGACGCGTAGCTCAACCTATCCATACCGAACTC; Reverse: CCGCTCGAGAAGCTGTGGGCTGAATCTAGTCTC (restriction sites are underlined). Secondly, the resulting construct was digested with SacI to remove sequence upstream of -767 and was re-circularized. All constructs were validated by sequencing.

\section{Cell culture, transfections, and luciferase assays}

Immortalized murine gonadotrope L $\beta$ T2 cells were provided by Dr Pamela Mellon (University of California, San Diego, CA, USA) and were cultured as described previously (Bernard 2004). Cells were plated and transfected in 6- or 24-well plates with Lipofectamine/Plus or Lipofectamine 2000 (Invitrogen) as previously described (Bernard 2004, Gore et al. 2005, Lamba et al. 2006). Specific treatment conditions are described in the text or figure legends where appropriate. For reporter assays, cells were washed with $1 \times$ PBS and lysed in $1 \times$ Passive Lysis Buffer (Promega). Luciferase assays were performed on a Luminoskan Ascent luminometer (Thermo Labsystems, Franklin, 
MA, USA) using standard reagents. All treatments were performed in duplicate or triplicate (as indicated), and each experiment was repeated two or more times.

\section{RT-PCR}

BMP family member mRNA expression was examined in adult male C57BL6/J mouse pituitary and L $\beta$ T2 total RNA using a MultiGene-12 RT-PCR Profiling Kit following the manufacturer's instructions using 35 cycles (SuperArray, PM-040B, Frederick, MD, USA). Forty percent of each reaction was resolved on a $1 \%$ agarose gel.

BMP receptor, Smad, activin subunit (all 35 cycles), and Rpl19 (25 cycles) mRNAs were amplified from L $\beta$ T2 cell, adult male C57BL6/J mouse pituitary, and adult female 129SvEv ovarian total RNA using the primer sets shown in Table 1 and previously described methods (Bernard 2004).

\section{Quantitative PCR}

Total RNA was isolated from L $\beta$ T2 cells in 12-well plates treated with activin A, BMP2 or the two in combination for approximately $24 \mathrm{~h}$. All treatments were performed in triplicate and the experiment repeated thrice. cDNA synthesis and real-time PCR were performed using an ABI7900HT (Applied Biosystems) as previously described (Yuen et al. 2002). Ribosomal protein S11 (Rps11), $\alpha$ tubulin (Tuba), and $\beta$-actin (Actb) mRNA levels were assayed in all samples. Fshb mRNA measurements were normalized using a robust global normalization algorithm. All control crossing threshold $(\mathrm{Ct})$ values were corrected by the median difference in all samples from actin. All samples were then normalized by the difference from the median Ct of the three corrected control gene Ct levels in each sample, with the value converted to a nominal copy number/cell by assuming 2500 actin mRNA molecules/cell and an amplification efficiency of $93 \%$. Sequences of PCR primers were as follows: Fshb forward: GAGAGCAATCTGCTGCCATAG, reverse: CCAGGCAATCTTACGGTCTC; Rps11 forward: CGTGACGAAGATGAAGATGC, reverse: GCACATTGAATCGCACAGTC; $A c t b$ forward: AGGTGACAGCATTGCTTCTG, reverse: GCTGCCTCAACACCTCAAC; Tuba forward: TGCGTTTGTGCACTGGTATG, reverse: CTGGAGCAGTTTGACGACAC. Data from replicates in individual experiments were averaged and these values used in statistical analysis such that $n=3$ per treatment.

\section{Immunoblots}

Whole cell protein extracts were prepared from L $\beta$ T2 cells treated as described in the text and subjected to immunoblot analyses as previously described (Bernard 2004). Briefly, equivalent amounts of protein were separated by SDS-PAGE (NuPage, Invitrogen) and transferred to Protran nitrocellulose filters (Schleicher and Schuell, Keene, NH, USA). Blots were probed with

Table 1 Primers used in RT-PCR analyses

Primer orientation

$\begin{array}{ll}\text { Gene } & \text { Forward } \\ \text { Inhba } & \text { Reverse } \\ \text { Inhbb } & \text { Forward } \\ \text { Bmpr2 } & \text { Reverse } \\ & \text { Forward } \\ \text { Acvr2a } & \text { Reverse } \\ & \text { Forward } \\ \text { Acvr2b } & \text { Reverse } \\ & \text { Forward } \\ \text { Acvr1 (ALK2) } & \text { Reverse } \\ \text { Bmpr1a (ALK3) } & \text { Forward } \\ \text { Bmpr1b (ALK6) } & \text { Reverse } \\ \text { Smad1 } & \text { Forward } \\ & \text { Reverse } \\ \text { Smad5 } & \text { Forward } \\ \text { Smad8 } & \text { Reverse } \\ & \text { Forward } \\ \text { Rpl19 } & \text { Reverse } \\ & \text { Forward } \\ & \text { Reverse } \\ & \text { Forward } \\ & \text { Reverse } \\ & \text { Forward } \\ & \text { Reverse }\end{array}$

Primer sequence

Size (bp)

5' CTTTCCTCATGCTGCAGGCTA $3^{\prime}$

5' CTAGGAGCAGCCACACTCCTC $3^{\prime}$

5' AGCTGGCCGTGGTGCCBGTGTT 3' 442

5' CACTCCTCCACRATCATGTTG $3^{\prime}$

5' AGGGATGACTTCCTCGCTGC 3'

5' AACTGGACGCTCATCCAAGG $3^{\prime}$

5' ATGGGAGCTGCTGCAAAGTTG 3'

5' GTGGTACCAAGGAATACAGCAG $3^{\prime}$

$5^{\prime}$ CGCGGAACATGACGGCGCCCT $3^{\prime}$

5' GATGAGAGAGAGGCCTCCAAT 3'

$5^{\prime}$ TTATACAATGGTCGATGGAG $3^{\prime}$

$5^{\prime}$ TTCAGGCGCTCTTGATTGC $3^{\prime}$

5' ATGACTCAGCTATACACTTACATCAG 3' 627

$5^{\prime}$ CAGGTCTTTCAATGATTCTCC $3^{\prime}$

$5^{\prime}$ ATGCTCTTACGAAGCTCTGG $3^{\prime}$

$5^{\prime}$ TCCAGCCCAATGCTGTACCG $3^{\prime}$

$5^{\prime}$ TTACCTGCCTCCTGAAGACC $3^{\prime}$

$5^{\prime}$ TTCCGCATACACCTCTCCTC $3^{\prime}$

$5^{\prime}$ TTCCACCAACCCAACAACGC $3^{\prime}$

$5^{\prime}$ TTTGACAACAATCCCAGGCAG $3^{\prime}$

$5^{\prime}$ ACTTCCGGCCAGTTTGCTAC $3^{\prime}$

5' TGGGGATCTTGCAGACGGTG $3^{\prime}$

$5^{\prime}$ CTGAAGGTCAAAGGGAATGTG $3^{\prime}$

5' GGACAGAGTCTTGATGATCTC 3'
410

684

439

464

490

491

361

419

351

195 
the indicated antibodies using standard techniques. The pSmad2, pSmad1/5/8, and pp38 rabbit polyclonal antibodies were from Cell Signaling Technology, Inc. (Danvers, MA, USA). The $\beta$-actin and Inhbb mouse monoclonal antibodies were from Sigma and Diagnostic Systems Laboratories (Webster, TX, USA) respectively. Horse radish peroxidase (HRP) conjugated secondary antibodies were from Bio-Rad and enhanced chemiluminescence (ECL) Plus reagents was from GE Healthcare.

\section{Data analysis}

The data from replicate experiments were highly similar and were pooled for statistical analyses. Data are presented as fold-change from the control condition in each experiment. Differences between means were compared using one- or two-way analyses of variance followed by post hoc Tukey tests where appropriate (Systat 10.2, Richmond, CA, USA). In some cases, data were log-transformed prior to analyses to control for unequal variances. Significance was assessed relative to $P<0 \cdot 05$.

\section{Results}

\section{BMP6 and 7 modestly regulate $F s h b$ transcription in L $\beta$ T2 cells}

A previous report showed that both BMP6 and 7 stimulated ovine Fshb $(\mathrm{o} F s h b)$ reporter activity in pituitaries of transgenic mice and in transiently transfected LBT2 cells (Huang et al. 2001c). Here, we examined regulation of murine $F_{s} h b(\mathrm{~m} F s h b)$ promoter-reporter activity by recombinant BMP 6 and 7 in L $\beta$ T 2 cells. Activin

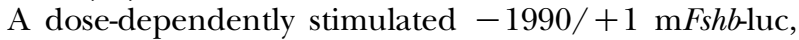
but the BMPs only modestly increased reporter activity 1.6- to $1 \cdot 9$-fold at the highest concentration tested, $5 \mathrm{nM}$ (Fig. 1). Similarly, BMP7 failed to stimulate endogenous Fshb mRNA levels in L $\beta \mathrm{T} 2$ cells at concentrations up to $100 \mathrm{ng} / \mathrm{ml}(\sim 3.3 \mathrm{nM}$; data not shown), whereas both activin A and B had potent effects at this and lower doses (Bernard 2004). We confirmed that BMP ligands used here were biologically active (data not shown).

\section{Various BMP family members are expressed in adult pituitary gland and L $\beta T 2$ cells}

We next asked whether other BMP family members might have more potent effects on Fshb transcription than BMPs 6 or 7. We used RT-PCR to determine which BMPs are expressed in L $\beta$ T2 cells and adult murine pituitary, and therefore might regulate FSH endogenously. The patterns of mRNA expression as assessed by RT-PCR differed between the two RNA populations

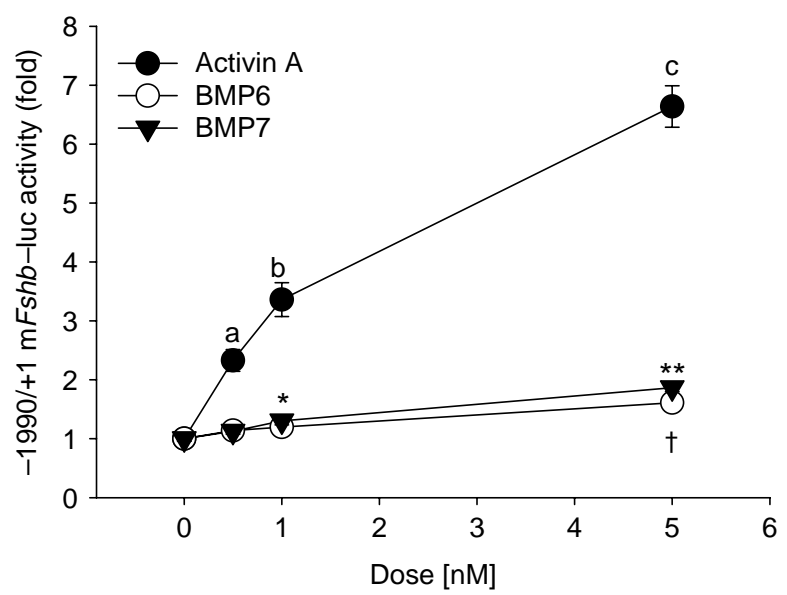

Figure 1 Activin A, but not BMP6 or 7, strongly regulates Fshb transcription. $L \beta T 2$ cells seeded in 6 -well plates were transfected with the $-1990 /+1 \mathrm{mFshb}$-luc reporter and treated with 0, 0.5, 1, $5 \mathrm{nM}$ recombinant activin A, BMP6, or BMP7 in serum-free medium for approximately $24 \mathrm{~h}$. Cell lysates were collected and assayed for luciferase activity. Data are presented as fold difference from the control condition (0) set to 1 and represent the mean ( \pm S.E.M.) of two independent experiments performed in triplicate $(n=6)$. Points with letters differ from control cells, and those with different letters differ from one another. Significant stimulation by BMP6 or 7 is indicated by * or $\dagger$ respectively.

(Fig. 2A). Whereas both expressed BMPs 6, 7, and $8 \mathrm{~b}$ at comparable levels, BMP8a levels were higher in L $\beta$ T2 cells and BMPs 2, 3, 3b, 4, and 5 were all greater in pituitary gland. Of particular note was the expression of BMP2 and 4 in pituitary, as these ligands have been implicated in pituitary organogenesis and cellular differentiation (Rosenfeld et al. 2000). Although they are expressed at very low levels in L $\beta$ T2 cells, their expression in other pituitary cell types in the adult suggested that these ligands could act as paracrine regulators of gonadotrope cells and we therefore probed their roles in Fshb transcription.

\section{BMPs 2 and 4 stimulate murine Fshb transcription}

L $\beta$ T2 cells were transfected with $-1990 /+1 \mathrm{~m} F$ shb-luc and treated with $100 \mathrm{ng} / \mathrm{ml}$ recombinant BMP2, BMP4, BMP6, BMP7, activin A, and activin B for $24 \mathrm{~h}$. Both activins strongly stimulated transcription (Fig. 2B). Both BMP2 and 4 stimulated the reporter significantly, whereas BMP6 and 7 had only mild effects at the same dose, as demonstrated previously (Fig. 1). BMP2 and 4 did not stimulate transcription from the empty reporter vector, pGL3-Basic (data not shown). These data showed that BMP ligands can stimulate $F s h b$ transcription in concentration ranges comparable with those of the activins; however, BMP2 and 4 were both less potent than both activin A and B. Because of the similarities between BMP2 and BMP4 we observed here and in additional analyses, we focused on BMP2 in the following experiments. 

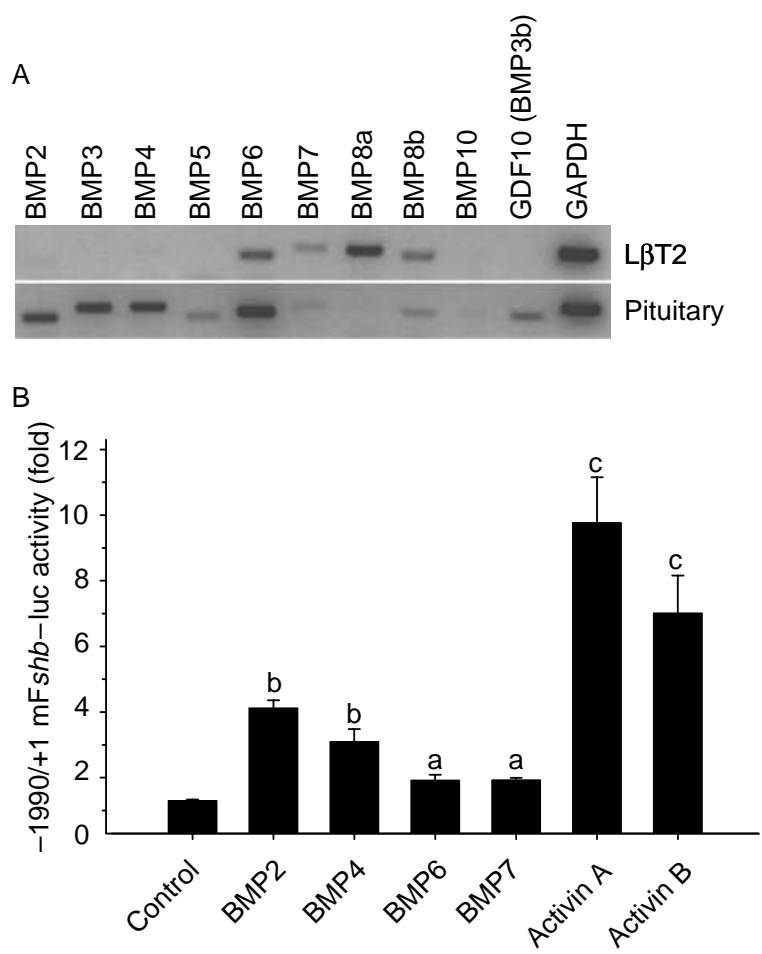

C

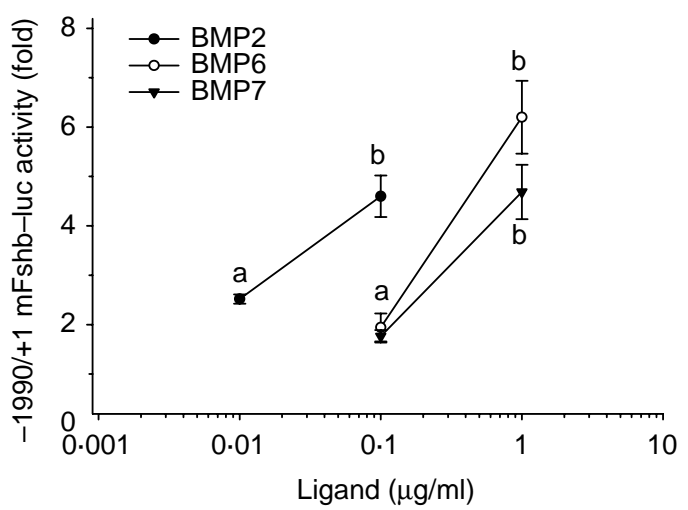

Figure 2 BMP family members are expressed in pituitary gland and regulate Fshb transcription. (A) The indicated BMP family members were amplified from $L \beta T 2$ cell and adult murine pituitary total RNA by RT-PCR. (B) L $\beta$ T2 cells seeded in 24-well plates were transfected with the $-1990 /+1 \mathrm{mFshb}$-luc reporter and treated in triplicate with $100 \mathrm{ng} / \mathrm{ml}$ indicated ligands for $24 \mathrm{~h}$. The data are from two independent experiments $(n=6)$. (C) Cells were transfected as in B and treated in triplicate with 0.01 or $0.1 \mu \mathrm{g} / \mathrm{ml}$ BMP2, or 0.1 or $1 \mu \mathrm{g} / \mathrm{ml} \mathrm{BMP6}$ or 7 for $24 \mathrm{~h}$. Data are from two experiments $(n=6)$. The data for the control group $(0 \mu \mathrm{g} / \mathrm{ml})$ are not pictured so that the remaining points can be presented on a log scale. In B and C, letters indicate significant differences from control. Points with different letters differ from one another.

A previous report indicated that at very high concentrations $(1 \mu \mathrm{g} / \mathrm{ml})$, BMP6 and 7 could stimulate ovine $F s h b$ reporter activity (Huang et al. 2001c). Here, we examined these high doses and their effects on the murine promoter relative to BMP2. The data indicated that BMP2 was about tenfold more potent than BMP6 or 7 in stimulating Fshb transcription (Fig. 2C).

\section{BMP2 and activin A synergistically stimulate Fshb transcription}

To gain a clearer understanding of the dynamics of BMP2's regulation of $F s h b$ transcription, we transfected cells with the $2 \mathrm{~kb} \mathrm{mFshb} \mathrm{reporter}(-1990 /+1)$ and stimulated with $25 \mathrm{ng} / \mathrm{ml}$ activin A or $100 \mathrm{ng} / \mathrm{ml} \mathrm{BMP} 2$ for 4,8 , or $24 \mathrm{~h}$. We also included a 24-h treatment group where the two ligands were added together. A greater concentration of BMP2 was used here to facilitate detection of changes occurring at earlier time points. As we reported previously (Lamba et al. 2006), activin A time-dependently increased transcription, reaching 14 -fold by $24 \mathrm{~h}$ (Fig. 3A). BMP2 similarly stimulated transcription in time-dependent fashion, peaking at fourfold at $24 \mathrm{~h}$. At no point was it more potent than activin A. Strikingly, the two ligands had a greater than additive effect (44-fold) on mFshb promoter activity at $24 \mathrm{~h}$. This synergistic activity was both unprecedented and unanticipated, and was therefore explored further.

To examine the specificity of this cooperativity, cells were treated with $25 \mathrm{ng} / \mathrm{ml}$ activin A in the presence or absence of $25 \mathrm{ng} / \mathrm{ml} \mathrm{BMP} 2,4,6$, or 7 (Fig. 3B). Both BMP2 and 4 potentiated the activin A response and did so proportionately to their independent effects. BMP6 and 7 alone did not significantly affect reporter activity nor did they augment the activin A response.

We next examined the effects of BMP2 alone and in combination with activin A on endogenous $F s h b$ mRNA levels to confirm that the responses we observed were not restricted to reporter gene activity. Activin A stimulated a 12-fold increase in Fshb mRNA levels as assessed by quantitative RT-PCR (Fig. 3C). BMP2 alone stimulated a twofold increase, but this was not statistically significant. Importantly, however, the two ligands synergized to increase $F s h b$ expression 27-fold, consistent with the reporter gene results.

\section{Activin A and BMP2 synergistically stimulate Fshb promoter-reporters of several species}

To determine the generality of the results observed here, we compared the actions of BMP2 alone and together with activin A on $F s h b$ promoter-reporters from mouse, pig, and sheep. These species were selected because the porcine promoter was shown recently to be highly activin A responsive in L $\beta$ T2 cells (West et al. 2004) and because activin regulation of the ovine Fshb promoter has been the subject of intensive study over the years (Huang et al. $2001 a, b, c$, Pernasetti et al. 2001, 

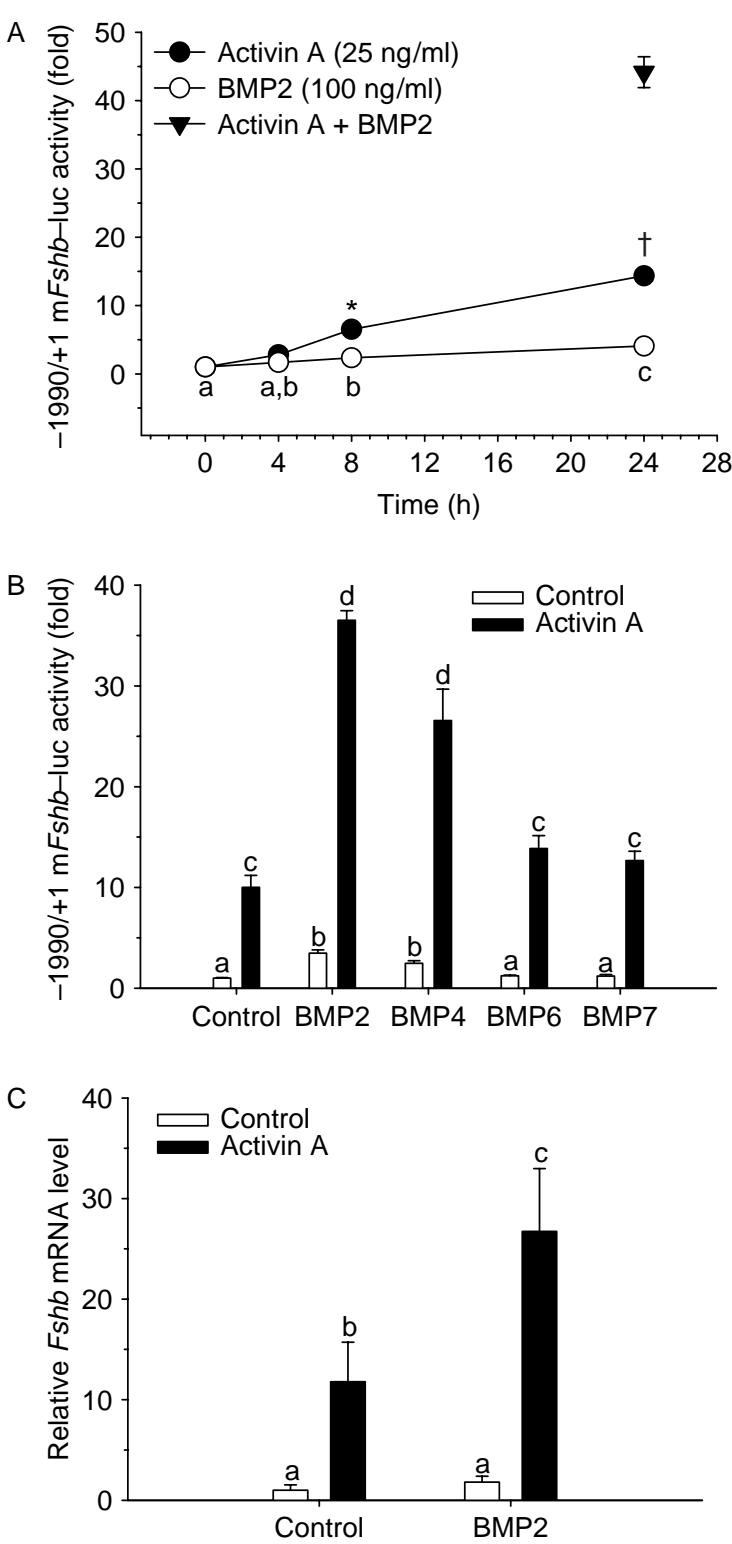

Figure 3 BMPs and activin A synergistically stimulate Fshb transcription. (A) L $\beta T 2$ cells seeded in 24 -well plates were transfected with the $-1990 /+1 \mathrm{mFshb}$-luc reporter and treated in triplicate with $25 \mathrm{ng} / \mathrm{ml}$ activin A or $100 \mathrm{ng} / \mathrm{ml} \mathrm{BMP} 2$ for 4,8 , or $24 \mathrm{~h}$, or with both ligands for $24 \mathrm{~h}$. Data are from three experiments $(n=9)$. Significant differences from control are indicated by letters or asterisk and dagger as described in previous figure legends.

(B) L $\beta$ T2 cells transfected with the $-1990 /+1 \mathrm{~m} F$ shb-luc reporter were treated in duplicate with $25 \mathrm{ng} / \mathrm{ml}$ activin A plus and minus $25 \mathrm{ng} / \mathrm{ml} \mathrm{BMP2}$, BMP4, BMP6, or BMP7 for $24 \mathrm{~h}$. The data are from three independent experiments $(n=6)$. (C) L $\beta T 2$ cells seeded in 12-well plates were treated with $25 \mathrm{ng} / \mathrm{ml}$ activin A plus or minus $25 \mathrm{ng} / \mathrm{ml}$ BMP2 for $24 \mathrm{~h}$. RNA was collected and endogenous Fshb mRNA levels measured by quantitative RT-PCR. All treatments were performed in triplicate and the experiment repeated thrice. Data are presented as mean fold-increase from the control condition (no ligands).
Bailey et al. 2004, Safwat et al. 2005). $5^{\prime}$ Flanking regions of comparable lengths for $F s h b$ from the different species were ligated into the pGL3-Basic reporter vector: $-846 /+1$ mouse, $-767 /+8$ pig, and $-763 /+91$ sheep. L $\beta$ T2 cells were transfected with these reporters or the empty vector and treated with combinations of activin A and BMP2. As shown in Fig. 4, both ligands independently stimulated reporter activity from the promoter constructs of all three species. None of the ligands alone or together affected activity of the pGL3-Basic. The porcine promoter was the most sensitive, and the sheep the least, of the three species tested. In all cases, synergy between activin A and BMP2 was observed, suggesting that this may be a general characteristic of $F s h b$ regulation. We observed similar synergism with BMP4 with all three promoters (data not shown). Finally, the murine $-846 /+1$ reporter here responded similarly to the $-1990 /+1$ reporter in previous analyses, allowing us to use these reporters interchangeably in subsequent experiments.

\section{Activin A and BMP2 do not alter the efficacy or timing of the other ligand's effects}

We next sought to establish the mode of cooperation between the two ligand types. First, L $\beta$ T2 cells were transfected with the $2 \mathrm{~kb} \mathrm{~m} F s h b$ reporter and were treated with a constant dose $(25 \mathrm{ng} / \mathrm{ml})$ of activin A for $24 \mathrm{~h}$. Some cells were simultaneously treated with varying doses $(0 \cdot 01-100 \mathrm{ng} / \mathrm{ml})$ of BMP2. At doses up to $1 \mathrm{ng} / \mathrm{ml}$, BMP2 had neither an effect on reporter activity nor did it alter the fold activin A response

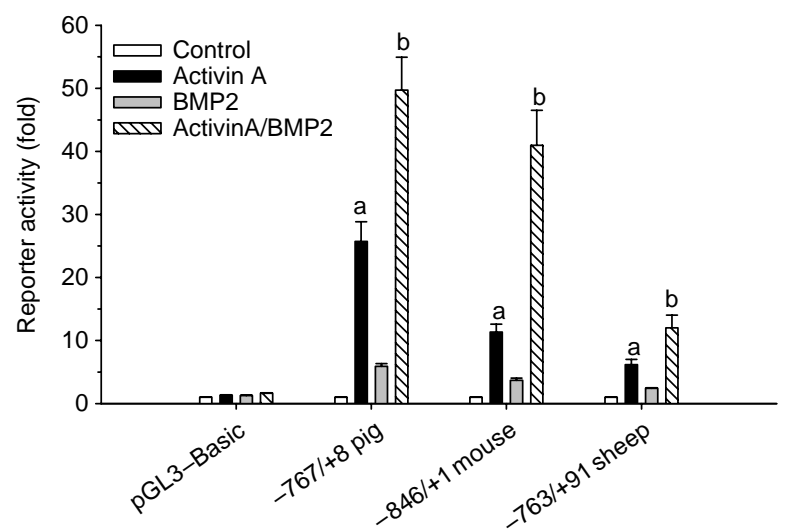

Figure 4 BMPs and activin A synergistically stimulate the porcine, murine, and ovine Fshb promoters in L $\beta$ T2 cells. L $\beta$ T2 cells seeded in 24-well plates were transfected with the indicated reporter constructs and treated with $25 \mathrm{ng} / \mathrm{ml}$ activin A plus or minus $25 \mathrm{ng} / \mathrm{ml}$ BMP2 for $24 \mathrm{~h}$. Treatments were performed in duplicate and the experiment repeated thrice $(n=6)$. Each reporter was analyzed using separate two-way (activin $\times B M P$ ) ANOVAs. Statistically significant differences are indicated with letters as described in previous legends. 
(Fig. 5A). At $10 \mathrm{ng} / \mathrm{ml}$, BMP2 stimulated Fshb transcription and appeared to potentiate the activin A effect. However, when normalizing for the increase in 'basal' activity attributable to BMP2, there was no change in the fold activin A response. At $100 \mathrm{ng} / \mathrm{ml}$, BMP2 further increased reporter activity and the overall magnitude of the synergistic effect with activin A, but once again did not alter the fold activin A response. Regardless of BMP2 dose, activin A stimulated reporter activity $10 \cdot 2$ - to $11 \cdot 8$-fold. We performed the reciprocal experiment, where a constant $25 \mathrm{ng} / \mathrm{ml} \mathrm{BMP2}$ dose was applied and activin A was added from $0 \cdot 01$ to $100 \mathrm{ng} /$ $\mathrm{ml}$ for $24 \mathrm{~h}$. Here, activin A dose-dependently stimulated reporter activity (with effects first observed at $10 \mathrm{ng} / \mathrm{ml}$ ) and synergized with BMP2, but did not significantly alter the fold BMP2 response at any dose (1·7- to 2-3-fold; data not shown).

Next, we examined whether BMP2 altered the timing of activin A's effects on transcription. Cells transfected
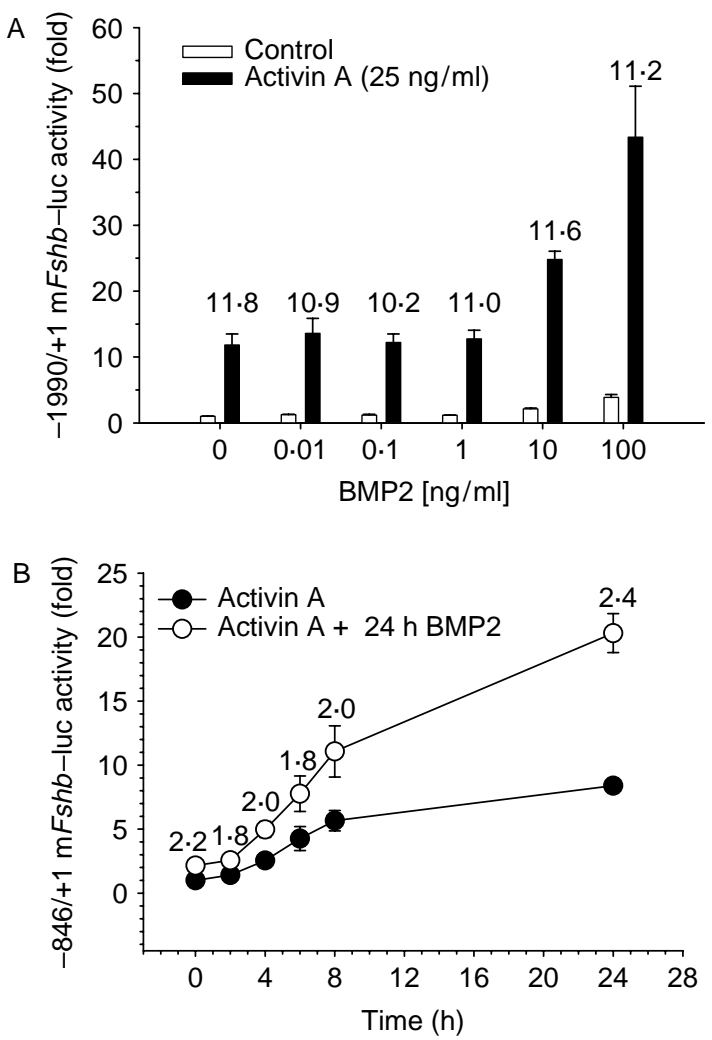

Figure 5 BMP2 and activin A do not alter the timing or magnitude of one another's responses. (A) L $\beta$ T2 cells seeded in 24-well plates were transfected with $-1990 /+1 \mathrm{mFshb}$-luc and treated with $25 \mathrm{ng} / \mathrm{ml}$ activin $A$ in the presence or absence of $0.01-$ $100 \mathrm{ng} / \mathrm{ml}$ BMP2 for $24 \mathrm{~h}$. The numbers above the bars reflect the fold activin A response at the different BMP2 doses. (B) L $\beta T 2$ cells seeded in 24-well plates were transfected with $-846 /+1 \mathrm{mFshb}$ luc and treated with $25 \mathrm{ng} / \mathrm{ml}$ BMP2 for $24 \mathrm{~h}$. Subsets of control and BMP2-treated cells were treated with $25 \mathrm{ng} / \mathrm{ml}$ activin A for 2 , $4,6,8$, or $24 \mathrm{~h}$. The numbers above the points indicate the fold BMP2 effect at the different times of activin A treatment. with the $-846 /+1 \mathrm{~m} F$ shb-luc reporter were treated with $25 \mathrm{ng} / \mathrm{ml}$ BMP2 for $24 \mathrm{~h}$ with or without $25 \mathrm{ng} / \mathrm{ml}$ activin A 24 (concurrently), 8, 6, 4, or $2 \mathrm{~h}$ before the end of the 24-h interval. In the presence or absence of BMP2, activin A began to stimulate reporter activity between 2 and $4 \mathrm{~h}$ and this timing was not altered by BMP2 treatment (Fig. 5B). As expected, the two ligands synergistically stimulated the $F s h b$ promoter, but activin A did not significantly alter the magnitude of the BMP2 response at any time point examined $(1 \cdot 8$ - to $2 \cdot 4$-fold, Fig. 5B). The reciprocal experiment produced comparable results, with BMP2 stimulating transcription between 2 and $4 \mathrm{~h}$ and the timing not being advanced or delayed by activin A (data not shown).

Collectively, these data suggest that the two ligands cooperatively stimulated the Fshb gene, but did not appear to do so by increasing cell sensitivity to the other ligand. Rather one ligand reset (increased) the "baseline' promoter activity and the other produced its characteristic response relative to that baseline. In this way, the two ligands synergized (multiplicatively) in terms of overall stimulation of $F s h b$ transcription, but appeared to do so using separable mechanisms (see more below).

\section{BMP2 effects in L $\beta T 2$ cells are modulated by, but not dependent upon, endogenous activin signaling}

Having demonstrated the interaction between exogenous activins and BMPs in $F s h b$ regulation, we next asked whether endogenous activin signaling in L $\beta$ T2 cells played a role in the observed BMP2 effects. Indeed, previous data suggested that endogenous activin signaling might be required for both basal and gonadotropin releasing hormone 1 (GNRH1)-regulated Fshbexpression in LBT2 cells (Pernasetti et al. 2001, Jacobs et al. 2003). In the case of BMP2, the question was particularly relevant because the ligand can stimulate transcription of the activin/inhibin $\beta \mathrm{B}$ (Inhbb) subunit (Jaatinen et al. 2002), and activin B (an Inhbb homo-dimer) appears to be the biologically relevant isoform in the pituitary (Corrigan et al. 1991). In the case of LBT2 cells, we observed Inhbb (Fig. 6A, middle panel), but not Inhba (Fig. 6A, top panel), mRNA expression, indicating they have the capacity to make activin B, but not activin A or activin $\mathrm{AB}$. We also observed that $100 \mathrm{ng} / \mathrm{ml} \mathrm{BMP} 2$ upregulated Inhbb protein levels (Fig. 6B) as well as stimulated rat Inhbb promoter activity in these cells (data not shown). Therefore, some of BMP2's actions on Fshb might not only be attributable to underlying activin B signaling, but also to a direct stimulation of activin's signaling capacity.

In light of these observations, we examined BMP2 activation of $F s h b$ transcription in the absence of endogenous activin B signaling. We treated cells with the ALK4/5/7 inhibitor, SB431542 (Inman et al. 2002). This compound is a competitive inhibitor of ATP 
A

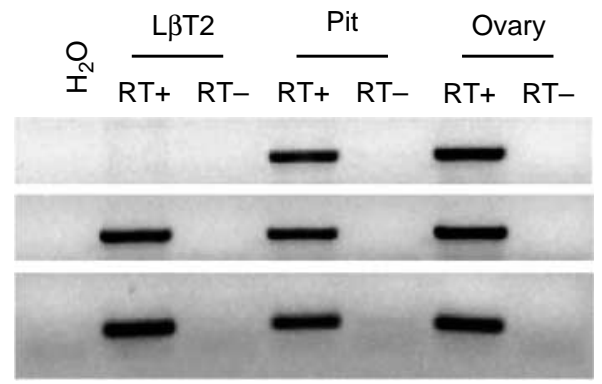

C

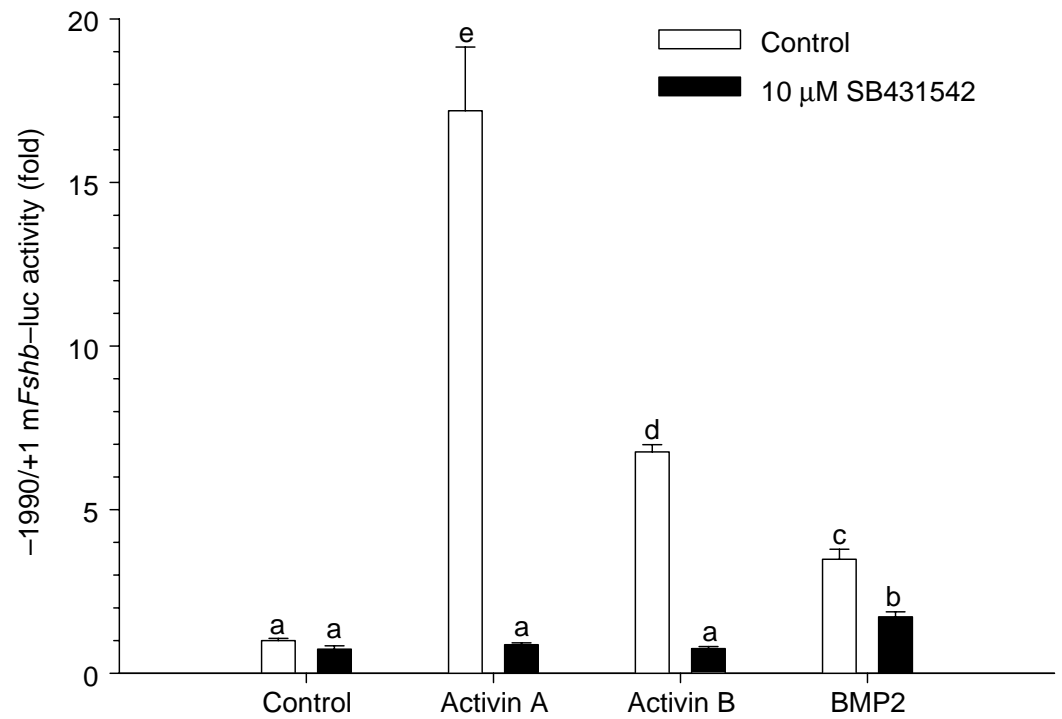

Figure 6 Endogenous activin B contributes to BMP2's stimulation of Fshb. (A) Inhba and Inhbb subunits were amplified from L $\beta T 2$ cell, adult mouse pituitary (Pit), and ovary total RNA by RT-PCR. Ribosomal protein L19 (Rp/19) was used as a loading control. RT + and RT- refer to samples in which the RT enzyme was included or omitted respectively. (B) L $\beta T 2$ cells in 6-well plates were treated with the indicated concentrations of BMP2 in serum-free medium for approximately $22 \mathrm{~h}$. Proteins were extracted and Inhbb levels detected by western blot under reducing conditions. $\beta$-Actin was used as a loading control. Markers at the left are in $\mathrm{kDa}$. (C) L $\beta T 2$ cells seeded in 24-well plates were transfected with $-1990 /+1 \mathrm{mFshb}$-luc and treated in triplicate for $24 \mathrm{~h}$ with $50 \mathrm{ng} / \mathrm{ml}$ activin A, activin B, or BMP2 in the presence or absence of $10 \mu \mathrm{M}$ SB431542. The data are from two independent experiments $(n=6)$. Bars with different letters differ significantly from one another.

binding to the receptors, but does not alter signaling capacity of the BMP type I receptors, ALK2, 3, or 6. In preliminary analyses, we found that at $10 \mu \mathrm{M}, \mathrm{SB} 431542$ completely inhibited activin A-and B-stimulated Fshb transcription in L $\beta$ T2 cells (data not shown and Fig. 6C) and had no effect on BMP2-stimulated BREX4-luc (Hata et al. 2000) activity in L $\beta$ T2 or HepG2 cells (data not shown). When L $\beta$ T2 cells were transfected with the $2 \mathrm{~kb} \mathrm{~m} F s h b$ reporter and treated with $10 \mu \mathrm{M}$ SB431542, we observed a $26 \%$ decrease in basal reporter activity and complete inhibition of both activin A and B stimulated transcription. In contrast, the BMP2 effect, while inhibited, was still $2 \cdot 3$-fold greater than basal in the presence of the inhibitor (Fig. 6C, compare bars 2 and 8). These data suggest that endogenous activin B signaling was not required for the BMP2 effect, although it did contribute to some extent to its overall magnitude.

\section{BMP receptors and receptor-regulated Smads are expressed in $L \beta T 2$ cells}

To better understand the molecular mechanisms through which BMP2 might transduce its effects on Fshb transcription, we examined mRNA expression for BMP type II receptors (Bmpr2, Acvr2a, and Acvr2b), type I receptors ( $A L K 2, A L K 3$, and $A L K G)$ and receptorregulated Smads (Smad1, 5, and 8 ) in LBT2 cells and adult pituitary. Consistent with previous reports (Pernasetti et al. 2001, Otsuka \& Shimasaki 2002, Dupont et al. 2003, 
Suszko \& Woodruff 2006), we readily detected the three type II receptor mRNAs as well as $A L K 2$ and $A L K 3$ mRNAs (Fig. 7). One report indicated no expression of $A L K 6$ in LßT2 cells or mouse pituitary (Otsuka \& Shimasaki 2002), whereas more recent work (Suszko \& Woodruff 2006) showed that it is expressed at low levels and our data are consistent with the latter report (Fig. 7). We show here for the first time that $\operatorname{Smad1}, 5$, and $8 \mathrm{mRNAs}$ are expressed in L $\beta$ T2 cells (Fig. 7).

\section{BMP2 can signal preferentially through BMPR2 and ALK2 to regulate Fshb expression}

To dissect mechanisms of BMP2 action without the confounding influence of endogenous activin B signaling (Fig. 6C), we performed the next series of experiments in the presence of SB431542. Like other TGF $\beta$ superfamily members, BMPs signal through hetero-tetrameric type II/type I receptor complexes (Allendorph et al. 2006). To determine which of the available type II receptors might be used by BMP2, cells

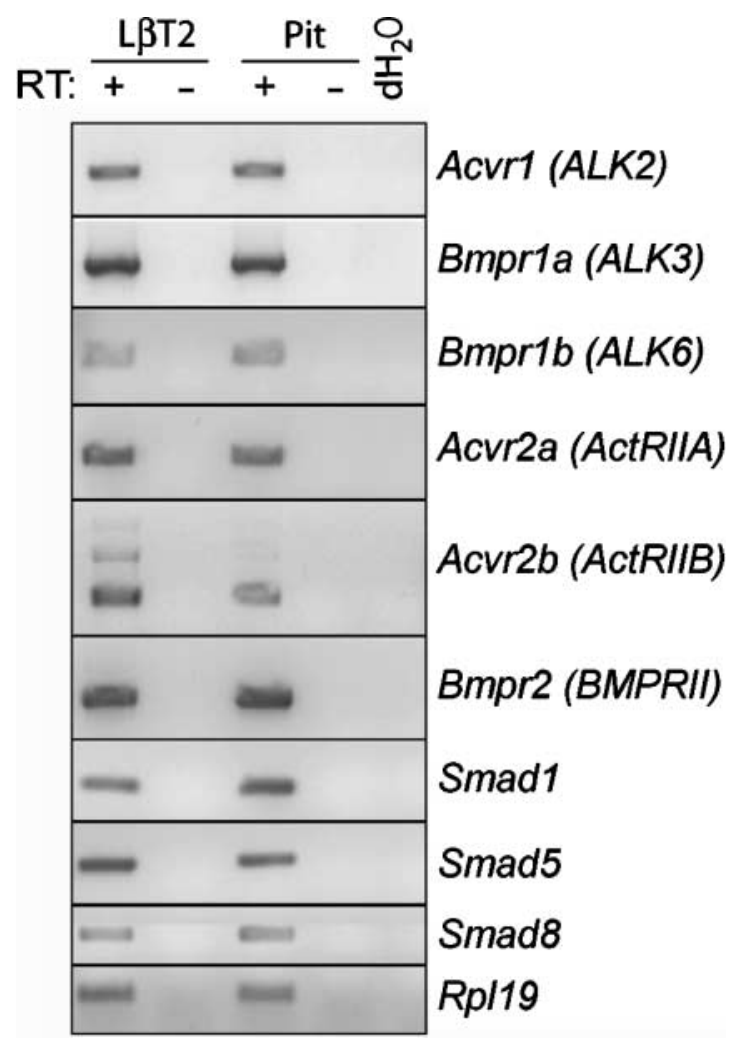

Figure 7 Expression of BMP signaling components in L $\beta$ T2 cells and adult mouse pituitary (Pit). BMP type I (ALK2, 3, and 6) and type II receptors (Acvr2a, Acvr2b, and Bmpr2), as well as signaling molecules (Smads 1, 5, and 8) were amplified from L $\beta T 2$ cells and adult mouse pituitary total RNA by RT-PCR. Rp/19 was used as a loading control. RT + and RT - are as described in Fig. 6. were transfected with the $-846 /+1 \mathrm{~m} F \mathrm{sh} b$ reporter and expression vectors for human BMPR2, rat Acvr2a, or rat Acvr2b, and treated with $25 \mathrm{ng} / \mathrm{ml} \mathrm{BMP2} \mathrm{for}$ $24 \mathrm{~h}$. In the presence of SB431542, $25 \mathrm{ng} / \mathrm{ml} \mathrm{BMP2}$ stimulated a $1 \cdot 5$-fold increase in reporter activity and this fold activation was not altered by Acvr2a or Acvr2b overexpression (Fig. 8A). Both of these receptors enhance activin A signaling when overexpressed in these cells (data not shown). In contrast, overexpression of BMPR2 significantly augmented the BMP2 response to $2 \cdot 5$-fold (Fig. $8 \mathrm{~A}$ ).

We took a similar approach to assess the potential role of specific type I receptors in the BMP response. In light of the low level of $A L K 6$ expression in these cells (Fig. 7; Otsuka \& Shimasaki 2002), we focused our attention on ALK2 and ALK3. We overexpressed rat ALK2 or human ALK3 alone and in combination with Acvr2a or BMPR2 with the $F s h b$ reporter. Neither type I receptor alone augmented the BMP2 response, nor did ALK3 in combination with either of the type II receptors (Fig. 8B). In striking contrast, ALK2 and BMPR2 together upregulated reporter activity in both the presence and the absence of ligand. These effects were specific as Acvr2a failed to synergize with ALK2. Collectively, these data suggest that BMP2 might preferentially act through complexes of BMPR2 and ALK2 receptors to regulate the Fshb promoter in these cells.

Because BMP2 also binds complexes of BMPR2 and ALK3 (ten Dijke et al. 1994, Liu et al. 1995), the functional differences between ALK2 and ALK3 in our system may reflect differences in intracellular signaling events mediated by these receptors (e.g. differences in modes of Smad activation, Macias-Silva et al. 1998, Chen $\&$ Massague 1999). To examine this idea in the absence of confounding effects of differences in relative affinity of BMP2 for BMPR2/ALK2 versus BMPR2/ALK3 complexes, we overexpressed constitutively active forms of the two receptors, ALK2QD and ALK3QD, which can signal in the absence of type II receptors and ligand (Hoodless et al. 1996). Remarkably, neither receptor alone stimulated $-846 /+1 \mathrm{~m} F s h$-luc activity in LBT2 cells in the presence of SB431542 (Fig. 8C). However, when co-expressed with BMPR2, which had no effect on its own, both receptors stimulated the $F s h b$ gene. Importantly, ALK2QD was more potent than ALK3QD in this assay, consistent with the hypothesis that the two receptors are not equivalent in activating intracellular signaling in this context.

\section{BMP2 preferentially signals through phospho-Smad8/4 to regulate Fshb transcription}

BMPs most frequently signal via activation (i.e. phosphorylation) of the receptor-regulated Smad proteins; however, Smad-independent signaling pathways have also been described (Derynck \& Zhang 

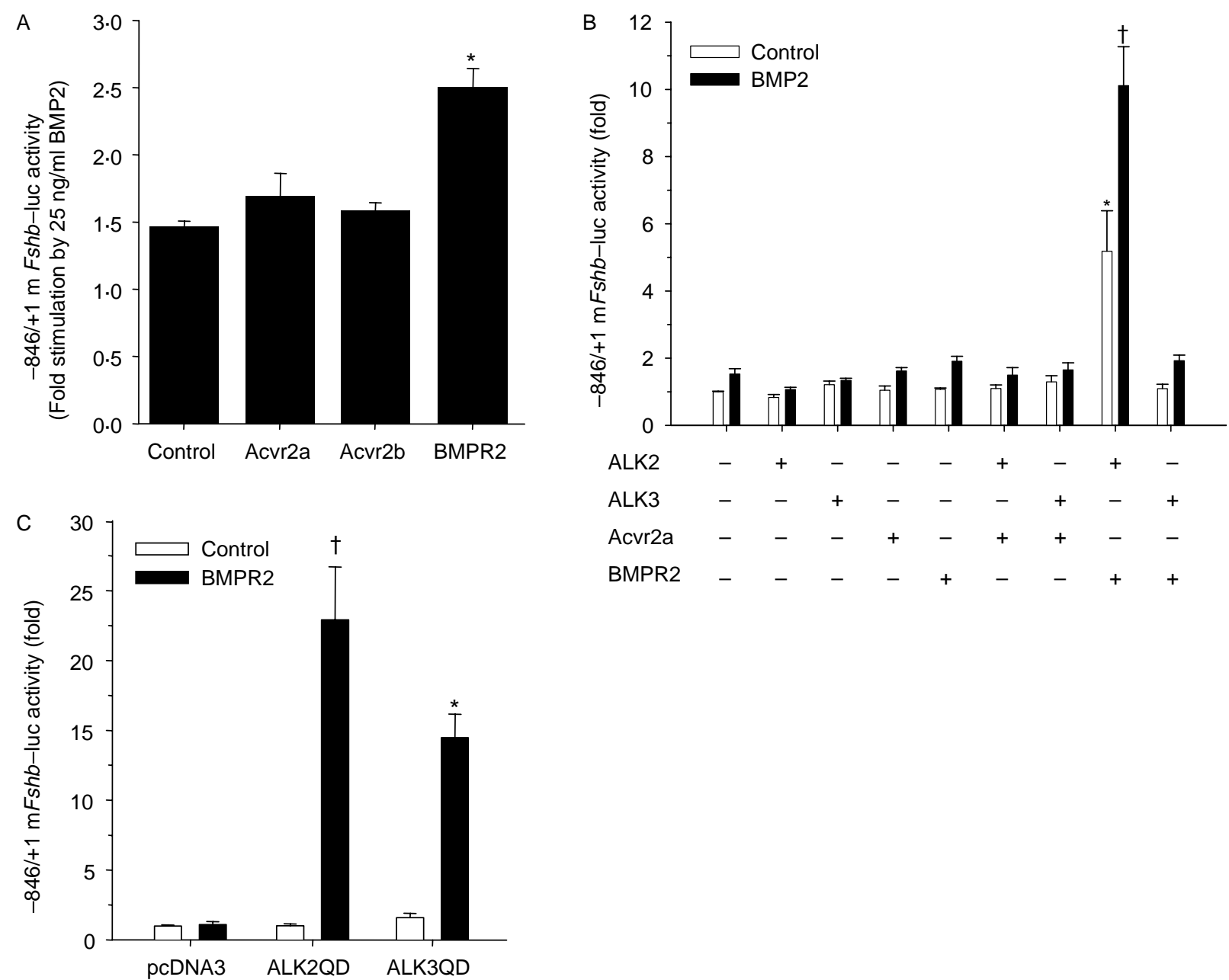

$\begin{array}{llllllllll}\text { ALK2 } & - & + & - & - & - & + & - & + & - \\ \text { ALK3 } & - & - & + & - & - & - & + & - & + \\ \text { Acvr2a } & - & - & - & + & - & + & + & - & - \\ \text { BMPR2 } & - & - & - & - & + & - & - & + & +\end{array}$

Figure 8 BMPR2 and ALK2 overexpression potentiate BMP2-regulated Fshb expression. (A) L $\beta$ T2 cells seeded in 24-well plates were transfected with $-846 /+1 \mathrm{mFshb}$-luc and the indicated receptor expression vectors. Cells were then treated in duplicate with $25 \mathrm{ng} / \mathrm{ml}$ BMP2 in the presence of $10 \mu \mathrm{M}$ SB431542. The data are from three independent experiments and are presented as the fold-stimulation by BMP2 in the presence of each of the receptors $(n=6)$. (B) Cells were transfected and treated as described in A, except here different type I (ALK2 or ALK3) and type II receptors (BMPR2 or Acvr2a) were introduced alone and together as indicated. Data are from three independent experiments with treatments performed in duplicate $(n=6)$ and are presented relative to the control group, in which no receptors or ligands were included. (C) L $\beta$ T2 cells seeded in 24-well plates were transfected in triplicate with $-846 /+1 \mathrm{mFshb}$-luc and the indicated receptor expression vectors. Cells were then treated with $10 \mu \mathrm{M}$ SB431542 for $24 \mathrm{~h}$ prior to analysis. The data are from three independent experiments $(n=9)$. In all panels, statistically significant differences from the control condition are indicated with asterisk and dagger.

2003). The data above suggested that BMP2 might use ALK2 as its signal propagating receptor and this receptor can activate Smads 1, 5, and 8 (Chen et al. 1997, Chen \& Massague 1999). We treated L $\beta$ T2 cells with $50 \mathrm{ng} / \mathrm{ml} \mathrm{BMP2}$, in the presence of SB431542, for various periods of time and measured Smad1/5/8 phosphorylation by western blot. As shown in Fig. 9A (top panel), BMP2 stimulated increases in the abundance of two bands detected by the pSmad1/5/8 antibody within 15-30 min, with the smaller of the two bands emerging first. We do not know the exact identities of these proteins as the antibody cross-reacts with phospho-Smads 1, 3, 5, and 8 and Smads 1 and 5 are the same size (465 amino acids). However, based on their relative molecular weights and the fact that BMP2 does not stimulate Smad3 phosphorylation in these cells (data not shown), we predict that the top band is a combination of pSmad 1 and $\mathrm{pSmad} 5$, and the bottom is pSmad8. Smads 1, 5, and 8 remained phosphorylated through 24-h treatment (data not shown). Although, it is possible that BMP2 activated Smad1/5/8-independent pathways in these cells, it failed to stimulate p38 mitogen activated protein kinase (MAPK) (Fig. 9A, second panel; Kimura et al. 2000) or Smad2 phosphorylation (Fig. 9A, third panel). Consistent with its effects on Fshb expression, BMP6 was about tenfold less 

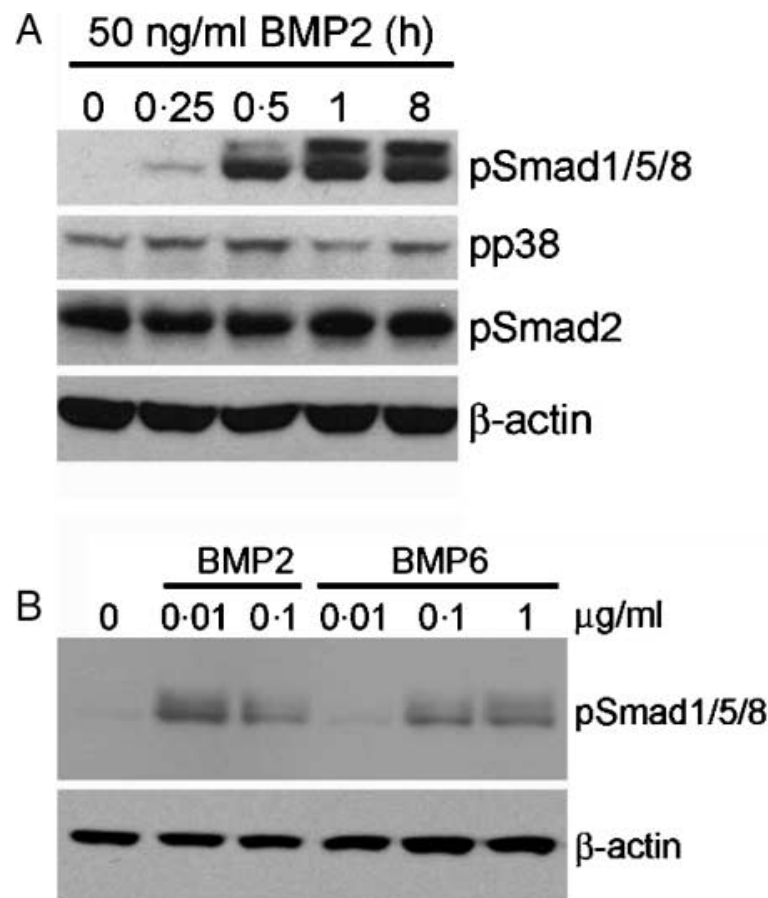

Figure 9 BMP2 activates the Smad1/5/8 pathway in L $\beta T 2$ cells. (A) L $\beta T 2$ cells seeded in 6-well plates were treated with $10 \mu \mathrm{M}$ SB431542 and then incubated with $50 \mathrm{ng} / \mathrm{ml}$ BMP2 for the indicated times. Protein lysates were subjected to western blot analyses and sequentially probed (top to bottom) with phosphoSmad1/5/8, phospho-p38, phospho-Smad2, and $\beta$-actin antibodies. (B) $L \beta T 2$ cells seeded in 6 -well plates were incubated with the indicated concentrations of BMP2 or BMP6 for approximately $1 \mathrm{~h}$. Western blots were performed on whole cell lysates using phospho-Smad1/5/8 (top) and $\beta$-actin (bottom) antibodies.

potent than BMP2 in stimulating Smad1/5/8 phosphorylation (Fig. 9B).

We next overexpressed Smads 1, 2, 3, 5, and 8 in L $\beta$ T2 cells along with the $-846 /+1 \mathrm{~m} F$ shb reporter treated with $25 \mathrm{ng} / \mathrm{ml} \mathrm{BMP2}$ in the presence of SB431542 for $24 \mathrm{~h}$. In the absence of ligand, Smads 1, 2,5 , and 8 alone had no effects on transcription as we reported previously for endogenous $F s h b$ mRNA levels (Bernard 2004; Fig. 10A). Smad3, however, strongly (69fold) stimulated the promoter (Suszko et al. 2003, Bernard 2004, Gregory et al. 2005, Suszko et al. 2005, Lamba et al. 2006). This effect did not require endogenous activin B signaling as it occurred in the presence of SB431542, although overexpressed Smad3 is known to translocate to the nucleus in the absence of active signaling (Reguly \& Wrana 2003). The fold BMP2 response was significantly enhanced by Smad8 (18.3- vs $2 \cdot 1$-fold) but not by the other R-Smads. These data suggested that Smad8 might be the preferred signaling protein in the BMP pathway, which is consistent with its rapid phosphorylation after ligand treatment in these cells (Fig. 9).
The R-Smads most often, though not always, act in concert with the co-Smad, Smad4, to mediate their effects (Lagna et al. 1996, Levy \& Hill 2005, He et al. 2006). We, therefore, examined the effects of overexpressed Smads 5 and 8 in the presence and the absence of Smad4. Again, Smad8, but not Smad5, alone potentiated the BMP2 effect (Fig. 10B). Smad4 alone had no effect on basal or BMP2-regulated transcription, but potentiated the Smad8 effect. Smad4 did not significantly alter the Smad5 response and similar results were observed with Smads 1, 2, or 3 (data not shown).

Smad8, like other receptor-regulated Smads, is principally regulated through C-terminal phosphorylation. Indeed, we observed increases in Smad8 phosphorylation in response to BMP2 (Fig. 9). To determine the necessity of this phosphorylation event, we overexpressed wild-type Smad8 and a mutated form that lacks the C-terminal serine residues that are phosphorylated by the activated type I receptor $(\operatorname{Smad} 8 \Delta \mathrm{C})$. Whereas Smad8 potentiated the BMP2 effect, Smad $8 \Delta \mathrm{C}$ failed to do so. Collectively, these data suggest that BMP2 stimulates the formation of pSmad8/Smad4 complexes that can regulate Fshb transcription.

Finally, to determine the time-course of BMP2's regulation of the $F s h b$ gene via $S m a d 8$, we transfected LBT2 cells with Smad8 and $-846 /+1 \mathrm{~m} F$ shb-luc, and then stimulated with BMP2 in the presence of SB431542 for $2,3,4,6,8$, or $24 \mathrm{~h}$. Increases in transcription were detected within $2-3 \mathrm{~h}$, peaked by $8 \mathrm{~h}$, and remained stable through $24 \mathrm{~h}$ (Fig. 10D). Thus, the effects mediated through this pathway were both rapid and delimited.

\section{Discussion}

The results presented here uncover several previously unappreciated aspects of TGF $\beta$ superfamily regulation of FSH synthesis. We show that BMP2: (1) stimulates Fshb subunit transcription and Fshb mRNA levels in LBT2 cells; (2) is approximately tenfold more potent than BMP6 or 7 in producing these effects; (3) synergizes with activin A to robustly upregulate $F s h b$ murine, porcine, and ovine promoter-reporter activities; (4) stimulates the Fshb promoter using a mechanism that is complementary to but distinct from that used by the activins; (5) preferentially signals through complexes of BMPR2 and ALK2 to regulate the Fshb gene; (6) stimulates Smad8 phosphorylation in L $\beta$ T2 cells and can use complexes of phospho-Smad8 and Smad4 to rapidly upregulate $F s h b$ transcription.

Previous analyses showed that BMP6 and 7 could stimulate FSH synthesis but only at high levels of the ligands (Huang et al. 2001c). Here, we see that BMP2 or 4 regulate $F s h b$ transcription at concentrations comparable 

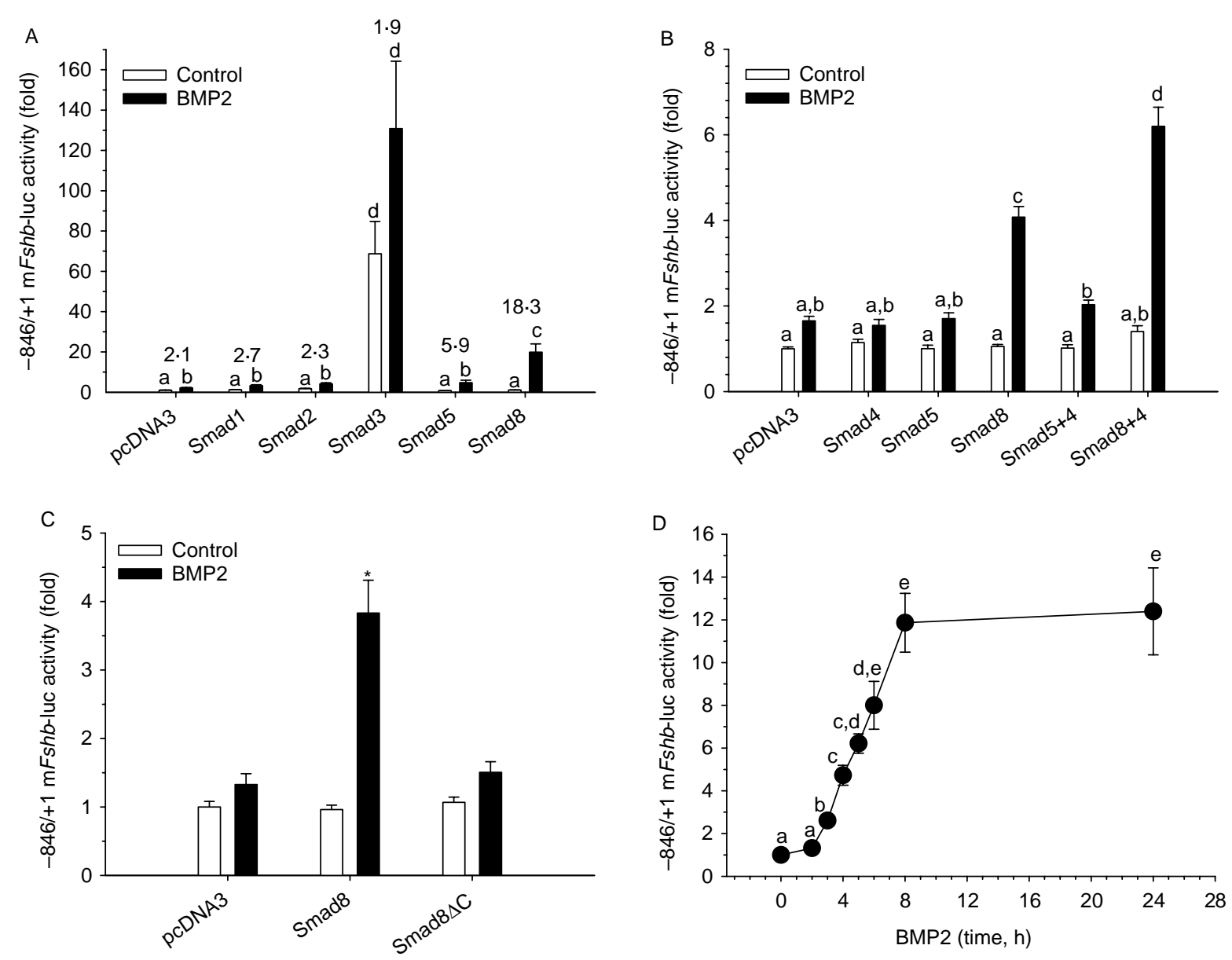

Figure 10 BMP2 rapidly activates Fshb transcription via pSmad8/4 complexes. (A) L $\beta T 2$ cells seeded in 24-well plates were transfected with $-846 /+1 \mathrm{mFshb}$-luc and the indicated Smad expression vectors (200 ng/well). Cells were then treated with $25 \mathrm{ng} / \mathrm{ml}$ BMP2 in the presence of $10 \mu \mathrm{M}$ SB431542. Numbers above the bars show the fold effect of BMP2 in the presence of the indicated Smads. (B) Cells were transfected and treated as described in A, except here Smad5 or Smad8 were introduced alone $(100 \mathrm{ng} /$ well) or with Smad4 (100 ng/well) as indicated. (C) Cells were transfected as in the previous panels with wild-type or Cterminally truncated Smad8 (100 ng/well). (D) L $\beta$ T2 cells in 24 -well plates were transfected with $-846 /+1 \mathrm{mFshb}-\mathrm{luc}$ and Smad8 (200 ng/well) and treated with $25 \mathrm{ng} / \mathrm{ml} \mathrm{BMP2}$ for $0,2,3,4,6,8$, or $24 \mathrm{~h}$ in the presence of $10 \mu \mathrm{M}$ SB431542. In all panels, data are from three independent experiments with treatments performed in duplicate $(n=6)$ and are presented relative to the control group, in which no Smads and/or ligands were included. Significant differences are shown with letters or asterisks as described above.

with those of the activins. Similar results were reported for BMP15 (Otsuka \& Shimasaki 2002); however, it is not clear that this ligand is an endogenous regulator of FSH in the pituitary. Although it is expressed in L $\beta T 2$ cells and adult mouse pituitary, the levels are very low. Moreover, BMP15 mRNA is not detectable in human or sheep pituitaries (Galloway et al. 2000, Takeda et al. 2003, Faure et al. 2005). In contrast, BMP2 and 4 are readily detected in adult mouse pituitary (Fig. 2A; Paez-Pereda et al. 2003). Both are also expressed in L $\beta \mathrm{T} 2$ cells, but at very low levels. If this pattern is reflective of pituitary in vivo, then both ligands would be predicted to act as paracrine, rather than autocrine, regulators of gonadotropes. We have not yet determined which cell type (s) in the pituitary make BMP2 and 4.
Although higher doses of BMP6 and 7 are required to stimulate FSH synthesis, BMP7 antibodies readily inhibit both ovine Fshb reporter activity in transgenic mice and FSH secretion from mouse, rat, and sheep primary pituitary cultures (Huang et al. 2001c). The effects of these antibodies on BMP2 or 4 were not investigated, but it is possible that there is some crossreactivity that could account for their observed actions on FSH. Alternatively, the pituitary may produce heterodimeric proteins, such as BMP2/7 or BMP4/7 and the antibodies might have antagonized their activities. These isoforms are generally more potent than BMP2 or 4 homodimers (Israel et al. 1996), so this intriguing possibility merits further consideration. The basis for differential potencies of BMP family members 
in this system is unknown, but is currently under investigation.

Perhaps the most surprising result from these analyses was the robust synergistic actions of BMP2 and activin A on Fshb transcription and mRNA levels. Overall, BMP2 was weaker than equimolar activin A in regulating gene expression, but together the two ligand types had greater than additive effects (multiplicative in the case of the murine promoter). Detailed analyses showed that neither ligand altered the magnitude or timing of the other ligand's effects. Rather, each appeared to produce independent effects of the Fshb promoter that in the aggregate generated profound increases in transcription. These observations suggest that the two ligands likely employ different, nonoverlapping mechanisms to generate their effects. If this is an accurate interpretation, then a specific analysis of mechanisms of BMP actions (see more below) should provide an understanding of both their independent and cooperative effects.

The activin A and BMP2 synergism in this system is surprising principally because these ligands more often have been shown to have antagonistic properties. For example, in developing Xenopus, activins induce dorsalization of mesoderm, whereas BMPs are ventralizing and can inhibit activin effects (Dale et al. 1992, Jones et al. 1992). The two ligand types activate different target genes and can inhibit each other's actions via competition for Smad4, which serves as a co-regulator for both activin (Smads 2 and 3) and BMP (Smads 1, 5, and 8) receptor-regulated Smads (Candia et al. 1997). More recently, activin A was shown to maintain pluripotency in human embryonic stems cells and to inhibit the differentiating effects of BMPs (Xiao et al. 2006).

Consistent with these opposing actions of the ligands and contrary to the results presented here, BMP4 was observed to suppress both basal and activin A-stimulated FSH secretion and Fshb mRNA levels in primary sheep pituitary cultures (Faure et al. 2005). The reason for the apparently discrepant results is not obvious. The trivial explanation of species differences does not seem to apply here as we specifically examined an ovine promoter-reporter in this system and saw the same pattern of results as in mouse and pig. Perhaps, differences in the intracellular milieu of L 3 T2 and ovine gonadotrope cells contribute to the different pattern of results. We, in fact, have seen that actions of TGF $\beta 1$ are distinct in L $\beta$ T2 cells and purified murine gonadotropes, whereas the actions of activin A are the same (Gore et al. 2005). Another possibility is that the analyses here involve a homogenous transformed cell population, whereas the previous work in sheep used mixed primary pituitary cell cultures. Therefore, in that study, BMP4 could have stimulated FSH in gonadotropes but these actions might have been overshadowed by effects of ligand on other cells in the culture. For example, BMPs can stimulate follistatin expression and release (Kearns \& Demay 2000, Abe et al. 2004). If they also stimulate follistatin production in folliculostellate (or gonadotrope) cells, this could explain BMP4 antagonism of basal and activin A stimulated FSH expression (Faure et al. 2005). Ultimately, the results obtained here need to be validated in both mixed pituitary and purified gonadotrope cell cultures to resolve these issues.

Receptor overexpression experiments showed that BMP2's actions were potentiated in the presence of BMPR2 and ALK2, but not Acvr2a, Acvr2b, or ALK3. While this approach does not definitively show that these are the receptors mediating the response in this cell line, it suggests that they may represent the preferred receptor combination. Transfection of dominant-negative forms of BMPR2 did not further clarify its role (data not shown). Therefore, we predict that knocking down expression of endogenous receptors (e.g. by RNAi) will be required to confirm their relative roles in this system. We did not examine ALK6 here because an earlier report indicated that it was not expressed in L $\beta$ T2 cells or adult mouse pituitary (Otsuka \& Shimasaki 2002). However, more recent work shows that this receptor is in fact expressed (Suszko \& Woodruff 2006), and we confirm this observation here. Given that ALK6 is more similar to ALK3 than ALK2, one would predict that it will not potentiate the BMP2 response. However, ALK3 and ALK6 do not always function identically (Zou et al. 1997, Chen et al. 1998); therefore, a role for ALK6 in this system merits a thorough examination.

It is interesting to note that none of the receptors examined here altered transcription in the absence of ligand and that ALK2's effects were only observed in the presence of co-expressed BMPR2 (Liu et al. 1995). Similarly, a constitutively active form of ALK2 (Q207D) failed to stimulate $F s h b$ transcription when expressed alone, but was effective when co-expressed with BMPR2 (Gilboa et al. 2000, Nohe et al. 2003). These data suggest that BMP2 may signal through pre-assembled receptor complexes to stimulate the Fshb promoter. Consistent with this idea, previous reports show that BMP2 can signal through pre-assembled complexes of BMPR2 and ALK3 to activate the Smad1/5/8 pathway and through ligand-induced signaling complexes to activate a Smadindependent, p38 MAPK, pathway (Nohe et al. 2002, Hassel et al. 2003). Indeed, here we observe that BMP2 rapidly activates Smad1/5/8, but not p38, phosphorylation. It still remains to be determined, however, whether ALK2 forms pre-assembled complexes with BMPR2 as has been described for ALK3.

Although Smads 1 and 5 are expressed in L $\beta$ T2 cells and appear to be phosphorylated in response to BMP2, neither Smad protein alone nor with Smad4 potentiated ligand-stimulated expression of Fshb. Instead, 
BMP2 appears to preferentially use Smad8, in concert with Smad4, to regulate this gene. Although these three Smads are structurally related, Smads 1 and 5 are more similar to each other than to $\operatorname{Smad} 8$ and the latter can activate transcription more efficiently than the former in some contexts (Pardali et al. 2005). Interestingly, BMP4 was shown to more efficiently activate Smad8 than was BMP7 (Aoki et al. 2001; similar to our results for BMP2 and BMP6), which could contribute to the differential effectiveness of the ligand types herein. Nonetheless, depletion of endogenous Smad protein levels will ultimately be required to determine their relative functions in BMP-regulated $F s h b$ expression (Bernard 2004, Suszko et al. 2005, Lamba et al. 2006).

The mechanisms through which Smad8 regulates the Fshb gene are not currently known. Thus far, we have established that BMP2 acting through Smad8 rapidly stimulates transcription and that its effect plateaus within $8 \mathrm{~h}$. This pattern of activation is distinct from that of activin $\mathrm{A}$, which stimulates a progressive increase in reporter activity through $24 \mathrm{~h}$ and beyond (Lamba et al. 2006). These observations are consistent with the hypothesized difference in mechanisms of activin A and BMP2 actions. We still do not know where in the Fshb promoter BMPs exert their actions or whether the effects are directly mediated by Smad8/Smad 4 binding. However, the observations that Smad8 remains phosphorylated through 24-h treatment but its effects on transcription do not increase beyond $8 \mathrm{~h}$ may provide some insight into the underlying process. For example, BMP2, via Smad8, may stimulate de novo synthesis of a protein directly targeting the $F s h b$ promoter and its synthesis may peak within the first 8-h treatment. Alternatively, BMP2 signaling could relieve the Fshb promoter from tonic repression that occurs under basal conditions. Such a de-repression mechanism is particularly appealing in light of the pattern of transcriptional activation observed in the presence of overexpressed Smad8.

In conclusion, the data presented here show that BMP2 independently and synergistically with activin A regulates the $F s h b$ subunit transcription in mouse. The mechanisms of BMP2 action are not yet completely understood; however, the ligand appears to signal through complexes of BMPR2 and ALK2 to activate a Smad8/4-dependent signaling cascade. Because follistatins and inhibins can antagonize BMP functions as well as those of the activins, the observations reported here may necessitate a revision or reformulation of current models of FSH regulation by TGF $\beta$ superfamily ligands.

\section{Acknowledgements}

The authors thank Drs W Miller, A Schneyer, and Y Sidis for providing helpful feedback on an early version of the manuscript. Drs Y Chen, J Massague, P Mellon, W Miller, E Robertson, P Scheiffele, T Watanabe, and T Woodruff provided valuable reagents. Cell culture work was performed in the Cell and Tissue Culture Core Facility of the Population Council under the direction of Dr Patricia Morris and with the assistance of Dr Deborah Lazzarino and Marion Davis.

\section{Funding}

This work was supported by NIH R03 HD44022 and R01 HD47794 to DJ B and RO1 DK4694 to S C S. The authors declare that there is no conflict of interest that prejudices the impartiality of the work presented.

\section{References}

Abe Y, Abe T, Aida Y, Hara Y \& Maeda K 2004 Follistatin restricts bone morphogenetic protein (BMP)-2 action on the differentiation of osteoblasts in fetal rat mandibular cells. Journal of Bone and Mineral Research 19 1302-1307.

Allendorph GP, Vale WW \& Choe S 2006 Structure of the ternary signaling complex of a TGF-beta superfamily member. PNAS 103 7643-7648.

Aoki H, Fujii M, Imamura T, Yagi K, Takehara K, Kato M \& Miyazono K 2001 Synergistic effects of different bone morphogenetic protein type I receptors on alkaline phosphatase induction. Journal of Cell Science 114 1483-1489.

Bailey JS, Rave-Harel N, McGillivray SM, Coss D \& Mellon PL 2004 Activin regulation of the follicle-stimulating hormone beta-subunit gene involves Smads and the TALE homeodomain proteins Pbxl and Prep1. Molecular Endocrinology 18 1158-1170.

Bernard DJ 2004 Both SMAD2 and SMAD3 mediate activin-stimulated expression of the follicle-stimulating hormone beta subunit in mouse gonadotrope cells. Molecular Endocrinology 18 606-623.

Besecke LM, Guendner MJ, Sluss PA, Polak AG, Woodruff TK, Jameson JL, Bauer-Dantoin AC \& Weiss J 1997 Pituitary follistatin regulates activin-mediated production of follicle-stimulating hormone during the rat estrous cycle. Endocrinology 138 2841-2848.

Candia AF, Watabe T, Hawley SH, Onichtchouk D, Zhang Y, Derynck R, Niehrs C \& Cho KW 1997 Cellular interpretation of multiple TGFbeta signals: intracellular antagonism between activin/BVg1 and BMP-2/4 signaling mediated by Smads. Development 124 4467-4480.

Chapman SC, Bernard DJ, Jelen J \& Woodruff TK 2002 Properties of inhibin binding to betaglycan, InhBP/p120 and the activin type II receptors. Molecular and Cellular Endocrinology 196 79-93.

Chen YG \& Massague J 1999 Smad1 recognition and activation by the ALK1 group of transforming growth factor-beta family receptors. Journal of Biological Chemistry 274 3672-3677.

Chen Y, Bhushan A \& Vale W 1997 Smad8 mediates the signaling of the ALK-2 (corrected) receptor serine kinase. PNAS 94 12938-12943.

Chen D, Ji X, Harris MA, Feng JQ, Karsenty G, Celeste AJ, Rosen V, Mundy GR \& Harris SE 1998 Differential roles for bone morphogenetic protein (BMP) receptor type IB and IA in differentiation and specification of mesenchymal precursor cells to osteoblast and adipocyte lineages. Journal of Cell Biology 142 295-305.

Cook RW, Thompson TB, Kurup SP, Jardetzky TS \& Woodruff TK 2005 Structural basis for a functional antagonist in the transforming growth factor beta superfamily. Journal of Biological Chemistry $\mathbf{2 8 0}$ 40177-40186. 
Corrigan AZ, Bilezikjian LM, Carroll RS, Bald LN, Schmelzer CH, Fendly BM, Mason AJ, Chin WW, Schwall RH \& Vale W 1991 Evidence for an autocrine role of activin $\mathrm{B}$ within rat anterior pituitary cultures. Endocrinology 128 1682-1684.

Dale L, Howes G, Price BM \& Smith JC 1992 Bone morphogenetic protein 4: a ventralizing factor in early Xenopus development. Development 115 573-585.

Derynck R \& Zhang YE 2003 Smad-dependent and Smad-independent pathways in TGF-beta family signalling. Nature 425 577-584.

Dupont J, McNeilly J, Vaiman A, Canepa S, Combarnous Y \& Taragnat C 2003 Activin signaling pathways in ovine pituitary and LbetaT2 gonadotrope cells. Biology of Reproduction 68 1877-1887.

Faure MO, Nicol L, Fabre S, Fontaine J, Mohoric N, McNeilly A \& Taragnat C 2005 BMP-4 inhibits follicle-stimulating hormone secretion in ewe pituitary. Journal of Endocrinology 186 109-121.

Galloway SM, McNatty KP, Cambridge LM, Laitinen MP, Juengel JL, Jokiranta TS, McLaren RJ, Luiro K, Dodds KG, Montgomery GW et al. 2000 Mutations in an oocyte-derived growth factor gene (BMP15) cause increased ovulation rate and infertility in a dosagesensitive manner. Nature Genetics 25 279-283.

Gilboa L, Nohe A, Geissendorfer T, Sebald W, Henis YI \& Knaus P 2000 Bone morphogenetic protein receptor complexes on the surface of live cells: a new oligomerization mode for serine/threonine kinase receptors. Molecular Biology of the Cell 11 1023-1035.

Gore AJ, Philips DP, Miller WL \& Bernard DJ 2005 Differential regulation of follicle stimulating hormone by activin A and TGFB1 in murine gonadotropes. Reproductive Biology and Endocrinology 373.

Gregory SJ, Lacza CT, Detz AA, Xu S, Petrillo LA \& Kaiser UB 2005 Synergy between activin A and gonadotropin-releasing hormone in transcriptional activation of the rat follicle-stimulating hormonebeta gene. Molecular Endocrinology 19 237-254.

Harrison CA, Gray PC, Vale WW \& Robertson DM 2005 Antagonists of activin signaling: mechanisms and potential biological applications. Trends in Endocrinology and Metabolism 16 73-78.

Hassel S, Schmitt S, Hartung A, Roth M, Nohe A, Petersen N, Ehrlich M, Henis YI, Sebald W \& Knaus P 2003 Initiation of Smaddependent and Smad-independent signaling via distinct BMPreceptor complexes. Journal of Bone and Joint Surgery. American Volume 85-A 44-51.

Hata A, Seoane J, Lagna G, Montalvo E, Hemmati-Brivanlou A \& Massague J $2000 \mathrm{OAZ}$ uses distinct DNA- and protein-binding zinc fingers in separate BMP-Smad and Olf signaling pathways. Cell 100 229-240.

He W, Dorn DC, Erdjument-Bromage H, Tempst P, Moore MA \& Massague J 2006 Hematopoiesis controlled by distinct TIFlgamma and Smad4 branches of the TGFbeta pathway. Cell 125 929-941.

Hoodless PA, Haerry T, Abdollah S, Stapleton M, O'Connor MB, Attisano L \& Wrana JL 1996 MADR1, a MAD-related protein that functions in BMP2 signaling pathways. Cell 85 489-500.

Huang HJ, Sebastian J, Strahl BD, Wu JC \& Miller WL $2001 a$ The promoter for the ovine follicle-stimulating hormone-beta gene (FSHbeta) confers FSHbeta-like expression on luciferase in transgenic mice: regulatory studies in vivo and in vitro. Endocrinology 142 2260-2266.

Huang HJ, Sebastian J, Strahl BD, Wu JC \& Miller WL $2001 b$ Transcriptional regulation of the ovine follicle-stimulating hormone-beta gene by activin and gonadotropin-releasing hormone $(\mathrm{GnRH})$ : involvement of two proximal activator protein-1 sites for GnRH stimulation. Endocrinology 142 2267-2274.

Huang HJ, Wu JC, Su P, Zhirnov O \& Miller WL 2001 $c$ A novel role for bone morphogenetic proteins in the synthesis of follicle-stimulating hormone. Endocrinology 142 2275-2283.

Inman GJ, Nicolas FJ, Callahan JF, Harling JD, Gaster LM, Reith AD, Laping NJ \& Hill CS 2002 SB-431542 is a potent and specific inhibitor of transforming growth factor-beta superfamily type I activin receptor-like kinase (ALK) receptors ALK4, ALK5, and ALK7. Molecular Pharmacology 62 65-74.
Israel DI, Nove J, Kerns KM, Kaufman RJ, Rosen V, Cox KA \& Wozney JM 1996 Heterodimeric bone morphogenetic proteins show enhanced activity in vitro and in vivo. Growth Factors 13 291-300.

Jaatinen R, Bondestam J, Raivio T, Hilden K, Dunkel L, Groome N \& Ritvos O 2002 Activation of the bone morphogenetic protein signaling pathway induces inhibin $\beta$-subunit mRNA and secreted inhibin B levels in cultured human granulosa-luteal cells. Journal of Clinical Endocrinology and Metabolism 87 1254-1261.

Jacobs SB, Coss D, McGillivray SM \& Mellon PL 2003 Nuclear factor Y and steroidogenic factor 1 physically and functionally interact to contribute to cell-specific expression of the mouse Folliclestimulating hormone-beta gene. Molecular Endocrinology 17 1470-1483.

Jones CM, Lyons KM, Lapan PM, Wright CV \& Hogan BL 1992 DVR-4 (bone morphogenetic protein-4) as a posterior-ventralizing factor in Xenopus mesoderm induction. Development 115 639-647.

Kearns AE \& Demay MB 2000 BMP-2 induces the expression of activin betaA and follistatin in vitro. Journal of Cellular Biochemistry 79 80-88.

Kimura N, Matsuo R, Shibuya H, Nakashima K \& Taga T 2000 BMP2induced apoptosis is mediated by activation of the TAK1-p38 kinase pathway that is negatively regulated by Smad6. Journal of Biological Chemistry 275 17647-17652.

Lagna G, Hata A, Hemmati-Brivanlou A \& Massague J 1996 Partnership between DPC4 and SMAD proteins in TGF-beta signalling pathways. Nature $383832-836$.

Lamba P, Santos MM, Philips DP \& Bernard DJ 2006 Acute regulation of murine follicle-stimulating hormone beta subunit transcription by activin A. Journal of Molecular Endocrinology 36 201-220.

Lebrun JJ \& Vale WW 1997 Activin and inhibin have antagonistic effects on ligand-dependent heteromerization of the type I and type II activin receptors and human erythroid differentiation. Molecular and Cellular Biology 17 1682-1691.

Levy L \& Hill CS 2005 Smad4 dependency defines two classes of transforming growth factor $\beta$ (TGF- $\beta$ ) target genes and distinguishes TGF- $\beta$-induced epithelial-mesenchymal transition from its antiproliferative and migratory responses. Molecular and Cellular Biology 25 8108-8125.

Lewis KA, Gray PC, Blount AL, MacConell LA, Wiater E, Bilezikjian LM \& Vale W 2000 Betaglycan binds inhibin and can mediate functional antagonism of activin signalling. Nature 404 411-414.

Liu F, Ventura F, Doody J \& Massague J 1995 Human type II receptor for bone morphogenic proteins (BMPs): extension of the twokinase receptor model to the BMPs. Molecular and Cellular Biology 15 3479-3486.

Macias-Silva M, Hoodless PA, Tang SJ, Buchwald M \& Wrana JL 1998 Specific activation of Smad1 signaling pathways by the BMP7 type I receptor, ALK2. Journal of Biological Chemistry 273 25628-25636.

Miyazawa K, Shinozaki M, Hara T, Furuya T \& Miyazono K 2002 Two major Smad pathways in TGF-beta superfamily signalling. Genes Cells 7 1191-1204.

Miyazono K 1999 Signal transduction by bone morphogenetic protein receptors: functional roles of Smad proteins. Bone 25 91-93.

Nohe A, Hassel S, Ehrlich M, Neubauer F, Sebald W, Henis YI \& Knaus P 2002 The mode of bone morphogenetic protein (BMP) receptor oligomerization determines different BMP-2 signaling pathways. Journal of Biological Chemistry 277 5330-5338.

Nohe A, Keating E, Underhill TM, Knaus P \& Petersen NO 2003 Effect of the distribution and clustering of the type I A BMP receptor (ALK3) with the type II BMP receptor on the activation of signalling pathways. Journal of Cell Science 116 3277-3284.

Otsuka F \& Shimasaki S 2002 A novel function of bone morphogenetic protein-15 in the pituitary: selective synthesis and secretion of FSH by gonadotropes. Endocrinology 143 4938-4941.

Paez-Pereda M, Giacomini D, Refojo D, Nagashima AC, Hopfner U, Grubler Y, Chervin A, Goldberg V, Goya R, Hentges ST et al. 2003 Involvement of bone morphogenetic protein 4 (BMP-4) in pituitary prolactinoma pathogenesis through a Smad/estrogen receptor crosstalk. PNAS 100 1034-1039. 
Pardali K, Kowanetz M, Heldin CH \& Moustakas A 2005 Smad pathwayspecific transcriptional regulation of the cell cycle inhibitor p21(WAF1/Cip1). Journal of Cellular Physiology 204 260-272.

Pernasetti F, Vasilyev VV, Rosenberg SB, Bailey JS, Huang HJ, Miller WL \& Mellon PL 2001 Cell-specific transcriptional regulation of follicle-stimulating hormone-beta by activin and gonadotropinreleasing hormone in the LbetaT2 pituitary gonadotrope cell model. Endocrinology 142 2284-2295.

Reguly T \& Wrana JL 2003 In or out? The dynamics of Smad nucleocytoplasmic shuttling Trends in Cell Biology 13 216-220.

Rosenfeld MG, Briata P, Dasen J, Gleiberman AS, Kioussi C, Lin C, O'Connell SM, Ryan A, Szeto DP \& Treier M 2000 Multistep signaling and transcriptional requirements for pituitary organogenesis in vivo. Recent Progress in Hormone Research 55 1-13 (discussion 13-14).

Safwat N, Ninomiya-Tsuji J, Gore AJ \& Miller WL 2005 Transforming growth factor beta-activated kinase 1 is a key mediator of ovine follicle-stimulating hormone beta-subunit expression. Endocrinology 146 4814-4824.

Sidis Y, Mukherjee A, Keutmann H, Delbaere A, Sadatsuki M \& Schneyer A 2006 Biological activity of follistatin isoforms and follistatin like-3 are dependent on differential cell surface binding and specificity for activin, Myostatin and BMP's. Endocrinology 147 3586-3597.

Sugino H, Sugino K, Hashimoto O, Shoji H \& Nakamura T 1997 Follistatin and its role as an activin-binding protein. Journal of Medical Investigation 44 1-14.

Suszko MI \& Woodruff TK 2006 Cell-specificity of transforming growth factor-\{beta\} response is dictated by receptor bioavailability. Journal of Molecular Endocrinology 36 591-600.

Suszko MI, Lo DJ, Suh H, Camper SA \& Woodruff TK 2003 Regulation of the rat follicle-stimulating hormone beta-subunit promoter by activin. Molecular Endocrinology 17 318-332.

Suszko MI, Balkin DM, Chen Y \& Woodruff TK 2005 Smad3 mediates activin-induced transcription of follicle-stimulating hormone betasubunit gene. Molecular Endocrinology 19 1849-1858.

Takeda M, Otsuka F, Suzuki J, Kishida M, Ogura T, Tamiya T \& Makino H 2003 Involvement of activin/BMP system in development of human pituitary gonadotropinomas and nonfunctioning adenomas. Biochemical and Biophysical Research Communications 306 812-818.

ten Dijke P, Yamashita H, Sampath TK, Reddi AH, Estevez M, Riddle DL, Ichijo H, Heldin CH \& Miyazono K 1994 Identification of type I receptors for osteogenic protein-1 and bone morphogenetic protein-4. Journal of Biological Chemistry 269 16985-16988.

Thompson TB, Lerch TF, Cook RW, Woodruff TK \& Jardetzky TS 2005 The structure of the follistatin:activin complex reveals antagonism of both type I and type II receptor binding. Developmental Cell 9 535-543.

West BE, Parker GE, Savage JJ, Kiratipranon P, Toomey KS, Beach LR, Colvin SC, Sloop KW \& Rhodes SJ 2004 Regulation of the folliclestimulating hormone beta gene by the LHX3 LIM-homeodomain transcription factor. Endocrinology 145 4866-4879.

Wiater E \& Vale W 2003 Inhibin is an antagonist of bone morphogenetic protein signaling. Journal of Biological Chemistry 278 7934-7941.

Wiater E, Harrison CA, Lewis KA, Gray PC \& Vale WW 2006 Identification of distinct inhibin and TGFbeta binding sites on betaglycan: functional separation of betaglycan co-receptor actions. Journal of Biological Chemistry 281 17011-17022.

Woodruff TK, Besecke LM, Groome N, Draper LB, Schwartz NB \& Weiss J 1996 Inhibin A and inhibin B are inversely correlated to follicle-stimulating hormone, yet are discordant during the follicular phase of the rat estrous cycle, and inhibin A is expressed in a sexually dimorphic manner. Endocrinology 137 5463-5467.

Xiao L, Yuan X \& Sharkis SJ 2006 Activin A maintains self-renewal and regulates FGF, Wnt and BMP pathways in human embryonic stem cells. Stem Cells 24 1476-1486.

Yuen T, Wurmbach E, Pfeffer RL, Ebersole BJ \& Sealfon SC 2002 Accuracy and calibration of commercial oligonucleotide and custom cDNA microarrays. Nucleic Acids Research 30 e48.

Zou H, Wieser R, Massague J \& Niswander L 1997 Distinct roles of type I bone morphogenetic protein receptors in the formation and differentiation of cartilage. Genes and Development 11 2191-2203.

Received in final form 21 October 2006 Accepted 6 November 2006 